\title{
Social Hydrological Analysis for Poverty Reduction in Community-Managed Water Resources Systems in Cambodia
}

\author{
Laura Forni $^{1, * \mathbb{C}}$, Susan Bresney ${ }^{2}$, Sophia Espinoza ${ }^{3}$, Angela Lavado ${ }^{4}$, Marina RL Mautner ${ }^{1}$, \\ Jenny Yi-Chen Han ${ }^{5}$, Ha Nguyen ${ }^{5}$, Chap Sreyphea ${ }^{6}$, Paula Uniacke ${ }^{7}$, Luis Villarroel ${ }^{8}$, Meloney Lindberg ${ }^{6}$, \\ Bernadette P. Resurrección ${ }^{8}$ and Annette Huber-Lee ${ }^{1}$
}

check for

updates

Citation: Forni, L.; Bresney, S.; Espinoza, S.; Lavado, A.; Mautner, M.R.; Yi-Chen Han, J.; Nguyen, H.; Sreyphea, C.; Uniacke, P.; Villarroel,

L.; et al. Social Hydrological Analysis for Poverty Reduction in Community-Managed Water Resources Systems in Cambodia. Water 2021, 13, 1848. https:// doi.org/10.3390/w13131848

Academic Editor: Marco Franchini

Received: 26 April 2021

Accepted: 25 June 2021

Published: 2 July 2021

Publisher's Note: MDPI stays neutral with regard to jurisdictional claims in published maps and institutional affiliations.

Copyright: (c) 2021 by the authors Licensee MDPI, Basel, Switzerland. This article is an open access article distributed under the terms and conditions of the Creative Commons Attribution (CC BY) license (https:// creativecommons.org/licenses/by/ $4.0 /)$.
1 Stockholm Environment Institute, U.S. Center, 11 Curtis Avenue, Somerville, MA 02144-1224, USA; marina.mautner@sei.org (M.R.M.); annette.huber-lee@sei.org (A.H.-L.)

2 Merrimack River Watershed Council, 60 Island St \#246, Lawrence, MA 01840, USA; sbresney@gmail.com

3 Independent Researcher, La Paz 2826, Bolivia; sofykantuta@gmail.com

4 Independent Researcher, Davis, CA 95616, USA; angelavado@gmail.com

5 Stockholm Environment Institute, Asia Center in Thailand, 10th Floor, Kasem Uttayanin Building, 254 Chulalongkorn University, Henri Dunant Road, Pathumwan, Bangkok 10330, Thailand; jenny.han@sei.org (J.Y.-C.H.); ha.nguyen@sei.org (H.N.)

6 The Asia Foundation, House No. 59 Oknha Peich (St 242), Phnom Penh 12101, Cambodia; sreyphea.chap@asiafoundation.org (C.S.); meloney.lindberg@asiafoundation.org (M.L.)

7 The Asia Foundation, 465 California St., 9th Floor, San Francisco, CA 94104-1804, USA; paula.uniacke@asiafoundation.org

8 Queen's University, 9 University Ave, Kingston, ON K7L 3N6, Canada; 1_villarro@yahoo.es (L.V.); babette888@gmail.com (B.P.R.)

* Correspondence: laura.forni@sei.org

Abstract: Achieving sustainable water resources management objectives can work in tandem with poverty reduction efforts. This study evidenced the strong social hydrological linkages that exist in Cambodia, which allowed for presenting a broader understanding of water resources challenges to better formulate and connect policies at the local and national levels. Models are often not developed with household- or community-level input, but rather with national- or coarse-level datasets. The method used in this study consisted of linking qualitative and quantitative social analysis with a previously developed technical water planning model. The results from the social inequalities analysis were examined for three water use types: domestic, rice production, and fishing in three parts of the watershed, namely, upstream, midstream, and downstream. Knowledge generated from the social analysis was used to refine previous water planning modeling. The model results indicate that without household data to consider social inequalities, the technical analysis for the Stung Chinit watershed was largely underrepresenting the shortages in irrigation supply seen by groups in the most downstream sections of the irrigation system. Without adding social considerations into the model, new policies or water infrastructure development suggested by the model could reinforce existing inequalities.

Keywords: water; inequality; poverty; IWRM; gender; rice; fishing; social-hydrological; environment; community

\section{Introduction}

Water resource challenges are difficult to define and solve because they are affected by the interlinkages of human and natural components [1]. Multiple human and natural linkages in relation to water can be highlighted. First, climate variability and its impacts on water supply availability [2]. Second, water demands for human consumption and productive uses, which are connected with the equitable access to and decision-making power over water resources [3]. Third, the sustainable management of those resources, and the ecological constraints of natural ecosystems [4,5]. Managing water resources to ensure both 
the production of rice and a healthy aquatic ecosystem for fishing are essential for supporting the livelihoods and poverty reduction efforts of local communities in many countries in Asia [6]. Addressing poverty and inequality in water resources planning needs to be part of decision-making processes in order to respond to context-specific poverty [7-10], socio-economic conditions [11-13], and development path challenges [14,15]. Ensuring sustainability needs to balance the adequate management of natural resources while preserving the socio-economic activities of the people living in the watershed [16]. Without having an accurate understanding of the social and environmental challenges, development policies could exacerbate existing inequalities and poverty [17]. Inclusive management of resources can contribute to higher sustainability and more equitable socio-economic (and social) outcomes for the people living in the watershed [18-21]. The ability of technical analyses to respond to social inequality depends on how effectively they can be interlinked [3,22-25]. This study examined the linkages between hydrologic and social components to inform water resources management for the Stung Chinit watershed in Cambodia.

The assessment of change and variability in water supplies has benefited from advances in scientific models that represent the hydrological system and estimate plausible ranges of future basin climate conditions [26-28]. These climate conditions can be combined with expected changes in demands related to human activities and desired development paths, e.g., increase in agricultural production, expected population growth, and higher food demands for fishing activities [29]. Arriving at a selection of optimal water management options for sustainable future outcomes under deep uncertainty is often based on environmental parameters to define resilience and ecologically desired thresholds $[30,31]$. In comparing the outcomes from such thresholds, sustainability- and resilience-focused actions are based on physical and natural metrics without considering the effects on livelihood and socio-economic activity [32-34]. Analysis of complex environmental systems dynamics needs to be coupled with an assessment of the degree to which implementing such environmental thresholds would inhibit people's well-being in addition to the ecosystem services these systems provide.

While the consideration of economic and budgetary aspects has a long history in water resources analysis, the integration of sociopolitical factors into hydrologic modeling is much more novel [35-37]. In natural resources analysis more generally, social and power considerations have been incorporated into mathematical models through socio-ecological systems (SES) modeling, while, more recently, socio-hydrology has attempted to integrate human social responses into hydrological systems modeling specifically $[38,39]$. Even so, researchers often incorporate social factors during the results analysis and policy formation phases, rather than use social science research, particularly surrounding poverty and gender, to inform the model formulation process [40,41]. Recent efforts in stakeholderdriven participatory planning have proposed robust decision support (RDS), which adopts the analytical framework of robust decision making (RDM) [26], but it is embedded within a broadly subscribed participatory process to drive problem formulation, model definition, and alternative development [27]. By combining these processes and tools, a numerical hydrologic model can be constructed with the incorporation of local knowledge; however, it often fails to understand and incorporate the realities of poverty, gender, and social status.

In transitional economies [14], people's livelihoods are inextricably linked to natural resources, from access to safe drinking water in their homes to access to water for productive activities and fishing. Shifting hydrological conditions due to climate change, varying water-related challenges based on the location relative to water supply infrastructure in the watershed, increasing demands from socio-economic development activities, different gender roles and livelihoods in relation to natural resources, and growing environmental constraints add to this complexity [42-46]. In developing economies, poverty reduction efforts can be an important influence in places where productive activities and income depend on natural resources. In the case of Cambodia, rice production and fishing, which are heavily dependent on water resources, are the key sources of income and food security. Strategies that ensure water security have the potential to support poverty reduction 
and gender equality efforts; however, they can also aggravate existing inequalities or exclusionary water practices if such social considerations are not identified as part of the modeling process.

Efforts to reduce inequality from the governance and management around ecosystems must address the complexity and interdependency of the system components and the connections with the social context and factors inhibiting access to resources [25]. Ecosystem services marginality occurs when social groups are at the margins of ecological sustainability conditions [47]. This marginality or water access exclusion occurs when a group of people is located at the margins of social and ecological conditions that prevent them from accessing and utilizing natural resources [47]. These types of marginalizing conditions include location-based inequalities and environmental constraints that contribute to poverty.

Poverty indicators that demonstrate the influence and connection between water resources and poverty can help identify environmental and social conditions that contribute to the reduction of poverty and social inequalities. These findings on the environmental and social conditions can inform numerical hydrological models and RDS-based analytical frameworks. In 2018, the Oxford Poverty and Human Development Initiative [48] developed a global poverty index that considers many overlapping deprivations experienced by the poor. Access to safe and reliable water is one of the deprivations related to poverty. Multidimensional poverty analysis, such as the multidimensional poverty analysis (MDPA) framework [49] are useful tools for understanding the socio-economic realities within a watershed and allow for the adaptation of the analysis to these realities. Standard indices for monetary-based poverty indicators should not be the only way of measuring poverty, but they can add another wealth-related layer to the analysis. The wealth index is often used to rank households based on their assets. Addressing poverty and inequality in the access of resources can support decisions that link the biophysical components and the social components to ensure sustainability and secure people's livelihoods.

This paper describes the results from the incorporation of poverty and social inequality aspects into technical projects to establish that water security actions can also support the wellbeing of households in community-managed systems. A series of steps are suggested in which a qualitative analysis informs quantitative analytical tools. First, a literature review and key informant interviews informed the development of a survey. Results from the survey were then used to create actionable indicators and refine a water planning software application, namely, the Water Evaluation and Planning (WEAP) [50] software that was previously developed for the Stung Chinit watershed [29]. Using the insights gained from the qualitative analyses and the WEAP tool, we explored three main questions: 1 . How are water availability and water access related? 2. What inequities and experiences are revealed with finer-scale survey information that can inform water resource planning? 3. What insights are provided when poverty and gender are used to contextualize and inform water systems modeling formulations? This study shows how scientifically informed water management actions can ensure water security while also contributing to the reduction of location-based poverty induced by marginal ecological conditions.

\section{Materials and Methods}

Addressing social inequalities and poverty needs to include an understanding of the social context and the forces that affect them. The materials employed in this analysis include the output of a previous project that used the technical model [29] and the MDPA framework. The novelty in the analysis presented in this study corresponded to linking qualitative and quantitative frameworks from a diverse set of disciplines and multiple research teams to address poverty and inequality in connection to watershed-level planning. The Stung Chinit watershed was the case study used. The previous project was focused on water security in the Stung Chinit watershed using the WEAP software [29].

The methodology used in this study can be summarized in three steps (Figure 1). Step 1 involved a description of the case study and an understanding of the social context of 
poverty and inequality through a qualitative analysis based on a literature review and key informant interviews guided by the MDPA framework. Step 2 involved the development and implementation of a survey informed by step 1 to generate social indicators. Step 3 involved reformulation of the technical analysis in the hydrological WEAP model [29] to incorporate key messages from the social indicators from step 2. These three steps allowed for an integrated analysis of the social and environmental challenges by refining the technical analysis in WEAP to evaluate and compare with results from the previous study. This section of the document starts with a description of the case study, followed by a section on each of the methodological steps mentioned above.

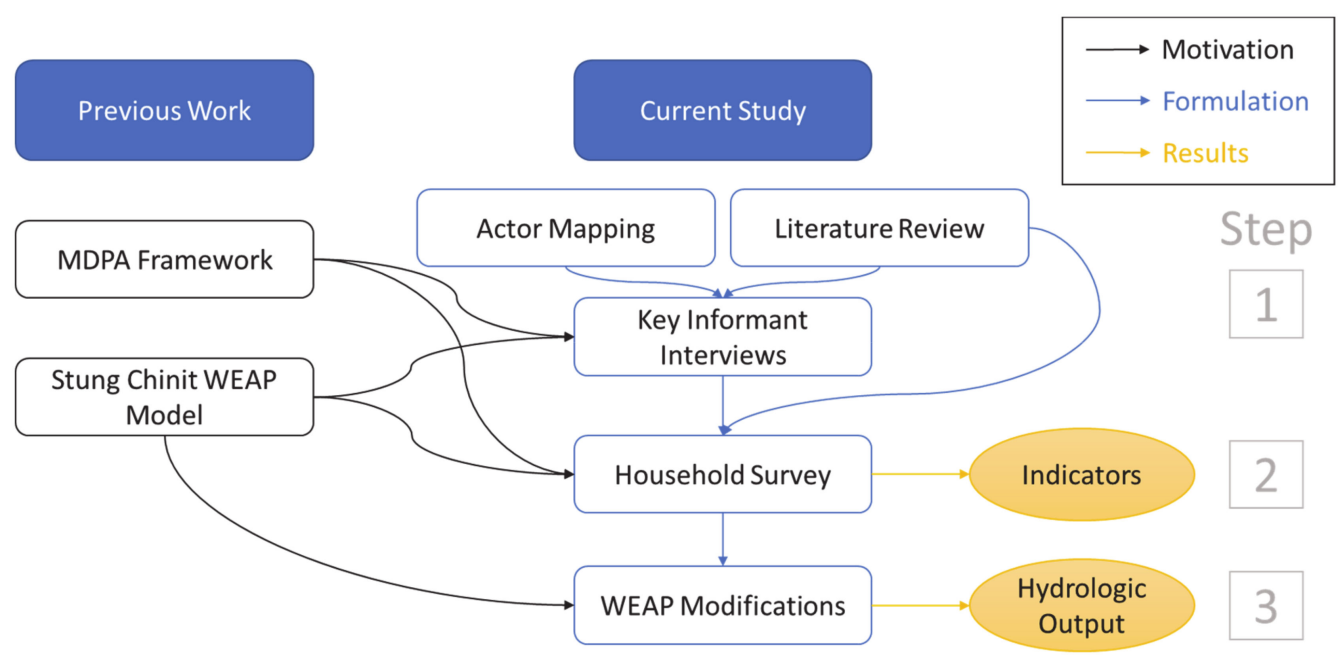

Figure 1. Flowchart of methods used.

\subsection{Stung Chinit Case Study}

The Chinit River (Stung Chinit) is an important source of life for the people and aquatic species that live within its $8236 \mathrm{~km}^{2}$ watershed (Figure 2). The residents rely heavily on the river to support rice farming and fishing as two main sources of food and livelihood [51,52]. Approximately $70 \%$ of the labor force in Cambodia is employed in agriculture [52], with that number being even greater in rural regions, such as the Stung Chinit basin, where approximately $90 \%$ of cropland is rice [53]. Agricultural expansion by expanding cultivated areas and maximizing yields continues to be an important goal for Cambodia, which is promoted by the government and the Asian Development Bank [54,55]. Rice cultivation, specifically, is a major consideration in the national food security effort [56,57].

Being a major tributary of the Tonle Sap Lake, the largest and most important lake in Cambodia both in terms of the economy and water supply, the Stung Chinit supports one of the world's most productive ecosystems and fishing economies [58]. While the river is an essential resource, heavy reliance on the Stung Chinit River and Tonle Sap floodplain also poses risks to both rice production and fisheries, and those who rely on them. Rice farmers struggle with limited development and low yields [53], while fisheries of the Tonle Sap are negatively affected by large-scale global changes, such as hydropower development, climate change, and urban migration [59].

The government of Cambodia has invested in the construction of many large-scale irrigation schemes in the upper part of Tonle Sap basin, and have granted concessions to private agribusinesses in the flood plains to promote rapid agriculture development and to fulfill the country's ambition of becoming one of the leading rice exporters [60]. National policies on economic development driven by rice exports affect local communities' access to water and aquatic resources. Such investment benefits private agri-investors, while many local communities have lost their traditional livelihood resources, such as wetlands for floating rice and grazing grounds for cattle [60]). These impacts and other challenges are not felt the same in all parts of the watershed. Most of the rice is rainfed, although 
there are two major irrigation schemes and a few small schemes that provide irrigation to improve yields and planting. However, these supply water to a small area $\left(<186 \mathrm{~km}^{2}\right)$ relative to the area of the watershed [29], disproportionately improving farming practices for some populations over others. Without management and coordination, these resources may cease to provide the functions necessary to sustain the populations that rely on them.

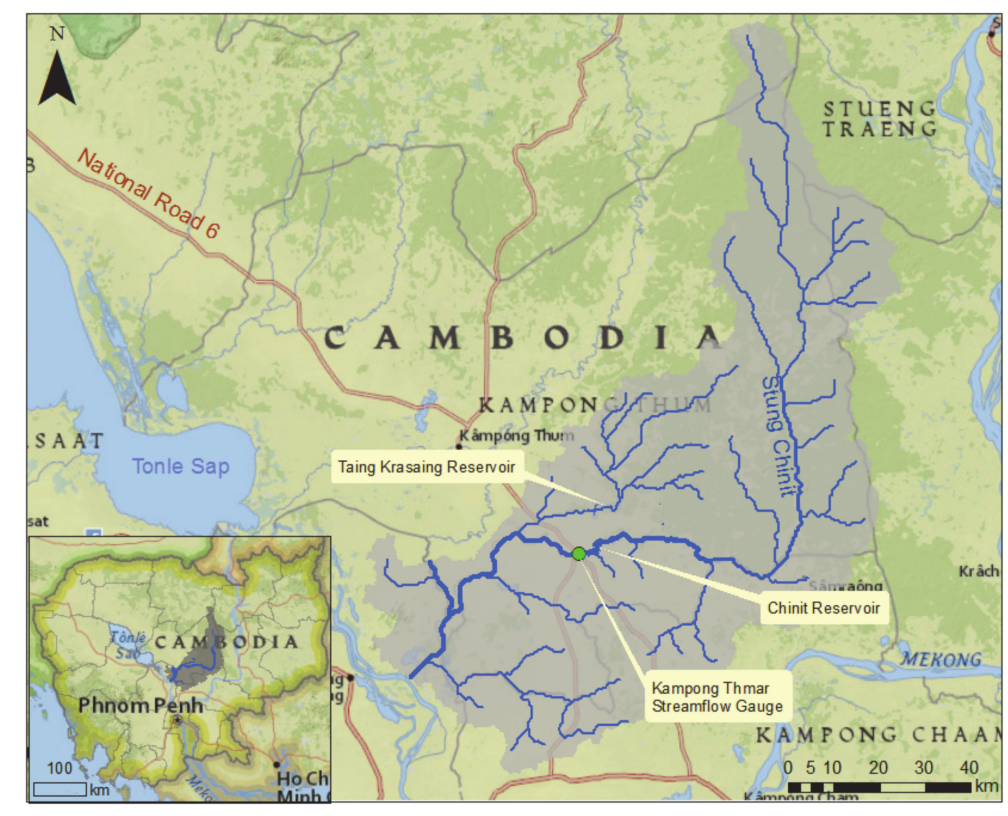

Figure 2. Map of the Stung Chinit Watershed and its location within Cambodia.

Upstream parts of the Stung Chinit watershed are affected by changes in forest cover, which affects downstream water availability for agricultural practices and other uses. Landuse management practices in the watershed can have both positive and negative impacts on water quantity (downstream water availability, groundwater recharge, runoff), and water quality (soil erosion, sedimentation, pollution), which in turn influence the ecological dynamics that support fisheries and agriculture. Discrepancies in the management of ecosystem services and policy interventions between the different parts of the watershed can leave people at the margins of unfavorable ecological conditions [61-63].

People in the Stung Chinit watershed depend on water for their socio-economic activities and the characteristics of the hydrological process and seasonality in the Stung Chinit impact people's social processes around rice cycles and fishing. A lack of access to water in this region can greatly deteriorate people's wellbeing [62].

\subsection{Qualitative Analysis on Poverty and Inequality Context}

The first step of the methodology is guided by multidimensional poverty analysis (MDPA) [49], starting with a literature review of the four poverty dimensions central to MDPA: resources, opportunities and choice, power and voice, and human security. The research design that guided the qualitative components of the analyses is included Table S1. The literature review is organized based on the search of keywords related to poverty dimensions, gender, and water-related management aspects. Relevant articles and papers were selected by experts from each of these fields of research based on their professional judgment. A total of 64 documents in English were reviewed; $52 \%$ were from peer-reviewed articles and $48 \%$ from the grey literature. Key aspects considered in the literature review correspond to the MDPA components shown in Figure 3. 


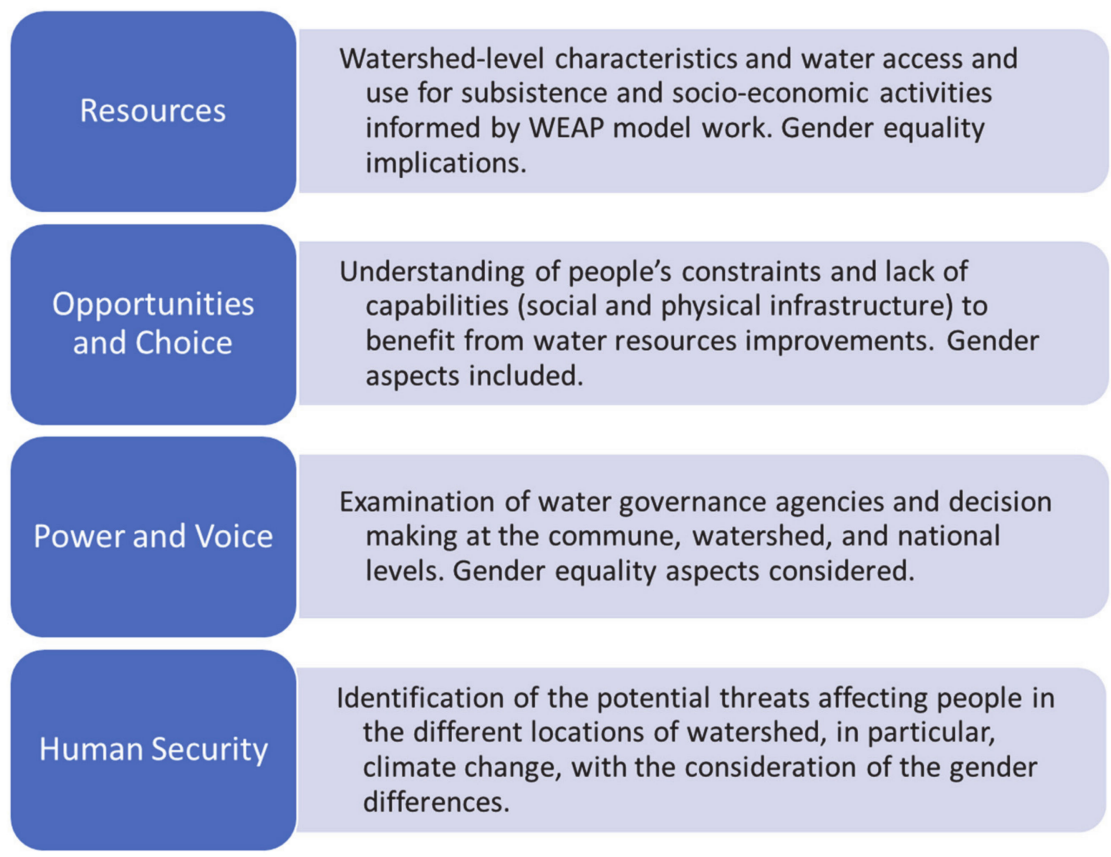

Figure 3. Multidimensional poverty analysis framework used to guide the literature review process.

The literature review provides the input for the key informants' interviews (KIIs) at the national and local levels containing questions regarding each of the four dimensions (Supplementary Material Document S2). To choose the key informants for the interviews, a map of actors was developed pertaining to different sectors at the local, provincial, and national levels (Table 1).

Table 1. Actor mapping of the KIIs.

\begin{tabular}{|c|c|}
\hline Scale & Name \\
\hline \multirow[t]{5}{*}{ National Government } & Freshwater Wetlands Conservation, Ministry of Environment (MoE) \\
\hline & $\begin{array}{c}\text { Department of Rural Water Supply at the Ministry of Rural } \\
\text { Development (MRD) }\end{array}$ \\
\hline & $\begin{array}{c}\text { Department of Gender and Equality and Department of Women and } \\
\text { Education, Ministry of Women's Affairs (MoWA) }\end{array}$ \\
\hline & $\begin{array}{c}\text { Department of Agricultural Engineering, Ministry of Agriculture } \\
\text { Forestry and Fisheries (MAFF) }\end{array}$ \\
\hline & Tonle Sap Authority (TSA) \\
\hline Provincial Government & $\begin{array}{l}\text { Agriculture Irrigation Office of Provincial Department of Water } \\
\text { Resources and Methodology }\end{array}$ \\
\hline \multirow[t]{2}{*}{ Local Government } & Stung Chinit Cheung Farmer Water User Committee (FWUC) \\
\hline & Beung Commune \\
\hline \multirow[t]{3}{*}{ Local Organization } & Beung Touk Fishery Community \\
\hline & Beung Kroy Fishery Community \\
\hline & Veal O'Kdey Community Forest \\
\hline \multirow[t]{3}{*}{ NGOs } & Winrock International \\
\hline & Cambodia Development Resource Institute \\
\hline & Oxfam Cambodia \\
\hline
\end{tabular}




\subsection{Survey Development and Implementation}

The information from the literature review and KIIs provided the input for a household survey to approximately 800 households, which were equivalent to about $1 \%$ of the total 110,668 households living in the Stung Chinit watershed (Supplementary Material Document S3). To have a good representation of the watershed and sex-disaggregated data, the survey was distributed in three locations: upstream, midstream, and downstream. The survey design was based on the key informants' interviews to assess the pervasiveness of the aspects identified in the KIIs. Questions to estimate the wealth index were included, as well as questions to fill data gaps in the WEAP model development from the previous project.

The sample of 800 was split equally across three regions along the Stung Chinit River watershed, namely, the upper watershed, middle watershed, and lower watershed, to have a representative sample to compare between regions. At the overall watershed level, survey statistics indicated a margin of error of about $\pm 3.5 \%$. The number of surveys for each region was 270 , with a margin of error of about $\pm 6 \%$ for each region. For the watershed level analysis, data weights (upstream 0.098 , midstream 1.59, downstream 1.30) were used to factor in population differences when we combined the data for all three regions. This ensured that each region contributed to the overall results and analysis as per its relative population. Table 2 shows the total number of households surveyed in each area of the watershed.

Table 2. Sample size and distribution.

\begin{tabular}{ccccc}
\hline & Total & Upper Watershed & Middle Watershed & Lower Watershed \\
\hline Households & 110,668 & 3612 & 58,235 & 48,821 \\
Sample & 800 & 270 & 270 & 270 \\
Households & & & & \\
\hline
\end{tabular}

The sample distribution within each region consisted of selecting 15 villages with 18 households in each village to obtain a sample size of 270 households. A total of 45 villages were surveyed across the three regions. To have a distribution of villages with varied population sizes, we divided the entire set of villages from a region into three groups based on their population: high population, medium population, and low population. From each of these three groups, we randomly selected five villages from those of each village population size to ensure that villages of all population sizes are reflected in the sample. Table 3 shows the total number of sample villages and sample households per village.

Table 3. Number of sample villages and sample households per village.

\begin{tabular}{lcccc}
\hline & Total & Upper Watershed & Middle Watershed & Lower Watershed \\
\hline Sample Villages & 45 & 15 & 15 & 15 \\
HHs per village & 18 & 18 & 18 & 18 \\
\hline
\end{tabular}

In selecting who within each household to survey, a survey protocol was established. All individuals surveyed had some decision-making power within the household and within each village, nine individuals were men and nine were women. Based on the survey, indicators were designed considering each of the four MDPA poverty dimensions (Table 4). Indicators were estimated by considering the relative frequency of the answers for each question used to design each indicator. Levels or categories for each indicator were mainly established based on the Sustainable Development Goals' (SDGs) monitoring indicators and literature about poverty and gender. Considering that some variables had missing data, it is important to mention that each indicator was approximated with a different number of observations. 
Table 4. List and description of indicators developed for the MDPA.

\begin{tabular}{|c|c|c|c|c|}
\hline $\begin{array}{c}\text { Poverty } \\
\text { Dimension }\end{array}$ & Water Use Sector & Indicator Name & Description & Unit of Measurement \\
\hline \multirow{4}{*}{ Resources } & $\begin{array}{l}\text { Drinking and } \\
\text { Domestic }\end{array}$ & $\begin{array}{l}\text { R1. Drinking water } \\
\text { availability }\end{array}$ & $\begin{array}{l}\text { Proportion of households who in } \\
\text { the past twelve months had enough } \\
\text { drinking water availability }\end{array}$ & $\begin{array}{c}\text { Percentage } \\
\text { (overall sample) }\end{array}$ \\
\hline & Rice Production & $\begin{array}{l}\text { R2. Water availability } \\
\text { for irrigation }\end{array}$ & $\begin{array}{c}\text { Proportion of households who had } \\
\text { enough water for irrigation the } \\
\text { past year }\end{array}$ & $\begin{array}{l}\text { Percentage in relation } \\
\text { to households that } \\
\text { practiced agriculture }\end{array}$ \\
\hline & Fishing & $\begin{array}{l}\text { R3. Resources } \\
\text { from fishing }\end{array}$ & $\begin{array}{l}\text { Proportion of households who had } \\
\text { resources from fishing for } \\
\text { food provision }\end{array}$ & $\begin{array}{c}\text { Percentage in relation } \\
\text { to households } \\
\text { that fished }\end{array}$ \\
\hline & Livestock & $\begin{array}{l}\text { R4. Resources } \\
\text { from livestock }\end{array}$ & $\begin{array}{l}\text { Proportion of households who had } \\
\text { resources from livestock, such as } \\
\text { income and/or food provision }\end{array}$ & $\begin{array}{l}\text { Percentage in relation } \\
\text { to households that } \\
\text { had livestock }\end{array}$ \\
\hline \multirow{4}{*}{$\begin{array}{l}\text { Opportunities } \\
\text { and Choice }\end{array}$} & $\begin{array}{l}\text { Drinking and } \\
\text { Domestic }\end{array}$ & $\begin{array}{l}\text { O1. Time } \\
\text { collecting water }\end{array}$ & $\begin{array}{l}\text { Proportion of households who } \\
\text { spend no time or less than } 30 \mathrm{~min} \\
\text { collecting water }\end{array}$ & $\begin{array}{c}\text { Percentage } \\
\text { (overall sample) }\end{array}$ \\
\hline & Rice Production & $\begin{array}{l}\text { O2. Water access } \\
\text { for irrigation }\end{array}$ & $\begin{array}{l}\text { Proportion of households who had } \\
\text { access to rice irrigation } \\
\text { for subsistence }\end{array}$ & $\begin{array}{l}\text { Percentage in relation } \\
\text { to households that } \\
\text { practiced agriculture }\end{array}$ \\
\hline & Fishing & O3. Access to fishing & $\begin{array}{l}\text { Proportion of households who had } \\
\text { access to fishing }\end{array}$ & $\begin{array}{c}\text { Percentage } \\
\text { (overall sample) }\end{array}$ \\
\hline & Livestock & $\begin{array}{l}\text { O4. Water access } \\
\text { for livestock }\end{array}$ & $\begin{array}{l}\text { Proportion of households who had } \\
\text { enough water for livestock in the } \\
\text { past twelve months }\end{array}$ & $\begin{array}{c}\text { Percentage in relation } \\
\text { to households that } \\
\text { had livestock }\end{array}$ \\
\hline \multirow{4}{*}{$\begin{array}{l}\text { Power and } \\
\text { Voice }\end{array}$} & $\begin{array}{l}\text { Drinking and } \\
\text { Domestic }\end{array}$ & $\begin{array}{l}\text { P1. Water supply } \\
\text { decisions at the } \\
\text { household level }\end{array}$ & $\begin{array}{l}\text { Proportion of households where } \\
\text { decisions about water supply were } \\
\text { made by female } \mathrm{HHH} / \text { male HHH } \\
\text { and spouse }\end{array}$ & $\begin{array}{c}\text { Percentage } \\
\text { (overall sample) }\end{array}$ \\
\hline & Rice Production & $\begin{array}{l}\text { P2. Access to } \\
\text { the FWUC }\end{array}$ & $\begin{array}{l}\text { Proportion of households who had } \\
\text { access to FWUC }\end{array}$ & $\begin{array}{c}\text { Percentage } \\
\text { (overall sample) }\end{array}$ \\
\hline & Fishing & $\begin{array}{l}\text { P3. Fishing activities } \\
\text { decisions at the } \\
\text { household level }\end{array}$ & $\begin{array}{l}\text { Proportion of households where } \\
\text { decisions about fishing activities } \\
\text { were made by female } \mathrm{HHH} / \text { male } \\
\text { HHH and spouse }\end{array}$ & $\begin{array}{c}\text { Percentage in relation } \\
\text { to households } \\
\text { that fished }\end{array}$ \\
\hline & Livestock & $\begin{array}{l}\text { P4. Livestock activities } \\
\text { decisions at the } \\
\text { household level }\end{array}$ & $\begin{array}{l}\text { Proportion of households where } \\
\text { decisions about livestock activities } \\
\text { were made by female } \mathrm{HHH} / \text { male } \\
\text { HHH and spouse }\end{array}$ & $\begin{array}{l}\text { Percentage in relation } \\
\text { to households that } \\
\text { had livestock }\end{array}$ \\
\hline \multirow{4}{*}{ Human Security } & $\begin{array}{l}\text { Drinking and } \\
\text { Domestic }\end{array}$ & H1. Food shortage & $\begin{array}{l}\text { Proportion of households who did } \\
\text { not have food shortages in the past } \\
\text { twelve months }\end{array}$ & $\begin{array}{c}\text { Percentage } \\
\text { (overall sample) }\end{array}$ \\
\hline & Rice Production & $\begin{array}{l}\text { H2. Natural disasters' } \\
\text { effects on agriculture }\end{array}$ & $\begin{array}{l}\text { Proportion of households who did } \\
\text { not suffer some effects of natural } \\
\text { disasters on agriculture the past } \\
\text { twelve months }\end{array}$ & $\begin{array}{l}\text { Percentage in relation } \\
\text { to households that } \\
\text { practiced agriculture }\end{array}$ \\
\hline & Fishing & $\begin{array}{c}\text { H3. Natural } \\
\text { disasters' effects }\end{array}$ & $\begin{array}{l}\text { Proportion of households who did } \\
\text { not suffer some effects of natural } \\
\text { disasters the past twelve months }\end{array}$ & $\begin{array}{c}\text { Percentage } \\
\text { (overall sample) }\end{array}$ \\
\hline & Livestock & $\begin{array}{l}\text { H4. Natural disasters' } \\
\text { effects on } \\
\text { livestock activities }\end{array}$ & $\begin{array}{l}\text { Proportion of households who did } \\
\text { not suffer some effects of natural } \\
\text { disasters on livestock the past } \\
\text { twelve months }\end{array}$ & $\begin{array}{l}\text { Percentage in relation } \\
\text { to households that } \\
\text { had livestock }\end{array}$ \\
\hline
\end{tabular}




\subsubsection{Wealth Index}

The wealth index calculation is based on the DHS Wealth Index Construction [64]. The estimation of the wealth index for the Stung Chinit Watershed was also differentiated by upstream, midstream, and downstream location. By using the principal components analysis procedure, the wealth index places individual households on a continuous scale of relative wealth. Households are then separated into five wealth index quintiles to compare the influence of wealth on various indicators. To estimate the wealth index, variables adapted to the Stung Chinit watershed (Table 5) related to each household's ownership of selected assets and materials for housing construction were used. The wealth index is a useful tool when income and expenditures data are not available, and to identify differences between socio-economic groups. By estimating the wealth index and the quintile distribution, differences between the poorest and wealthiest households can be analyzed.

Table 5. List of variables included in the wealth index estimation.

\begin{tabular}{ccc}
\hline N & Variable & Explanation \\
\hline 1 & WI_MEMBERS ROOM & Number of people per bedroom \\
2 & WI_ELECTR & Home had electricity \\
3 & WI_RADIO & Home had a radio \\
4 & WI_TV & Home had a television \\
5 & WI_FURN & Home had furniture (bed, chairs, table, sofa, closet) \\
6 & WI_SOUND_EQ & Home had a mini-component or sound equipment \\
7 & WI_BIKE & Home had a bike \\
8 & WI_OVEN & Home had a kitchen (gas, electric, etc.), oven \\
9 & WI_WATER_PUMP & Home had a water pump \\
10 & WI_MOTORBIKE & Home had a motorbike \\
11 & WI_H_TRACTOR & Home had a hand tractor \\
12 & WI_F_BACKPACK & Home had a fumigation backpack \\
13 & WI_COOK_LPGGAS & Type of fuel house mainly used was LPG \\
14 & WI_COOK_STICKS & Type of fuel the house mainly used was wood or fuel sticks \\
15 & WI_FL_CEMENT & Main floor material was concrete or cement \\
16 & WI_FL_TILE & Main floor material was tile, ceramic, or mosaic \\
17 & WI_FL_WOOD & Main floor material was wood \\
18 & WI_ROOF_METAL & Main roof material was galvanized iron, aluminum, \\
19 & WI_ROOF_TILE & or other metal sheets \\
20 & WI_WALL_CEMENT & Main wall material was brick, concrete, cement, or stone \\
21 & WI_WALL_WOOD & Main wall material was wood, logs, or plywood \\
22 & WI_WALL_METAL & Main wall material was galvanized iron, aluminum, \\
23 & WI_GARB_BURN & or other metal sheets \\
\hline & & Usual way to dispose of garbage was to burn it \\
\hline
\end{tabular}

\subsubsection{Gender Analysis from Survey}

The gender analysis focused on three domains of water use: domestic water supply, agriculture/irrigation, and fishing. Gendered differences and patterns related to aspects of access and power across all domains were analyzed. Access was assessed based on the availability and sufficiency of different water options for households within the domain. Power, on the other hand, was assessed based on participation in discussions and decisionmaking at the household level and at the community/public level on the subject. Gender differences were examined via two parameters: gender of the survey respondent and gender of the household leadership figure. Specifically, we disaggregated data by gender of the respondents to examine perception, and by gender of the household leadership to examine power and influence in decision making at the household and community levels. In the analysis, the household head was determined through a combination of two survey questions that asked the respondents to identify the name and gender of the key decision makers in their families, thus classifying them as male-headed households or 
female-headed households. Qualitative information from the literature and the KIIs was also used to contextualize the quantitative findings.

\subsection{Quantitative Analysis on WEAP \\ Model and Scenario Reformulation}

The Water Evaluation and Planning (WEAP) software was used to represent the hydrology and water management within the Stung Chinit watershed. The initial WEAP model is described in [29], where it represents 12 catchments with varying land cover and 8 irrigation groups (Figure 4) that were given equal priority in the water management system. This meant that when insufficient water was available to meet the demand of all groups, all groups received the same shortage (as a percent of demand). Hydrology in the catchments was calculated using the WEAP soil moisture method, while irrigation demands in the irrigation groups were calculated using WEAP's MABIA method [65]. The MABIA method includes detailed information on crop scheduling, irrigation practices, and irrigation demand calculations based on the Food and Agriculture Organizations Drainage Paper [66]. It contains a daily simulation of transpiration, evaporation, irrigation requirements, irrigation scheduling, and crop growth and yields, and includes modules for estimating reference evapotranspiration and soil water capacity. Inputs for both methods include climate (rainfall, temperature, relative humidity, wind speed, and cloud coverage), irrigation schemes, soil information, land-use types, and crop characteristics. Future scenarios are developed for both the changing climate and increased crop production.
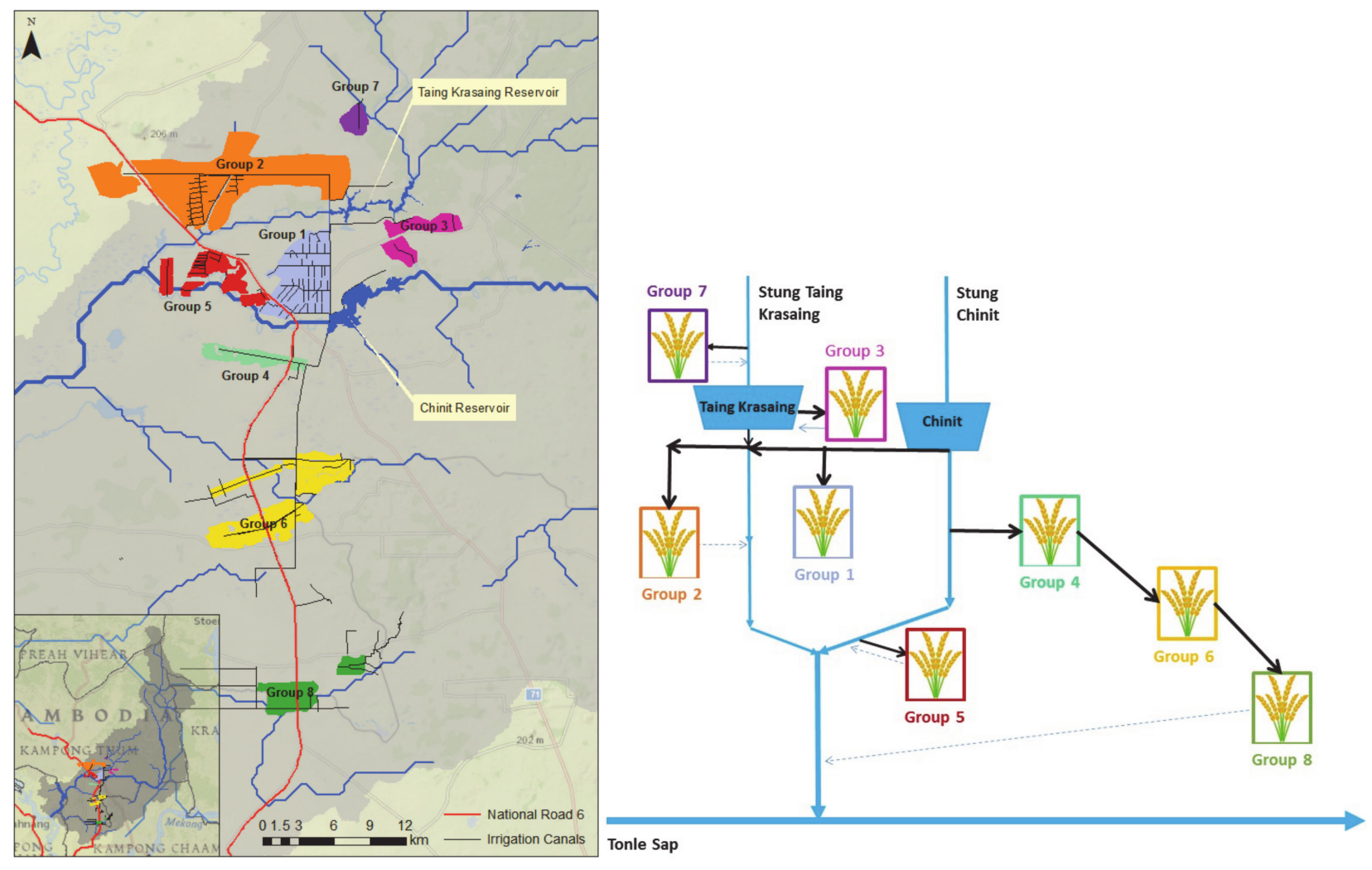

Figure 4. Map of the Stung Chinit Watershed and irrigation schemes (left), and schematic of the Chinit and Taing Krasaing reservoirs and irrigation schemes (right). The area serviced by each irrigation scheme was called a group, labeled with a number, and shown in the colored areas on the map (left). The schematic (right) shows the same groups and how they received water from the reservoirs. Arrows show the flow of water. Blue solid lines indicate rivers, black lines indicate irrigation water going to the groups, and blue dotted lines indicate return flows to the system.

This previous model used all information available at the time it was developed to assess water availability in the Stung Chinit watershed for rice production and the ecosys- 
tem habitat. It assessed the potential impacts that climate change and water management practices may have on that availability. The demands were originally represented with equal priorities for all irrigation groups because insufficient information was available to support a different assumption. Additionally, the model failed to assess water access as it assumed that if water was available, it could be accessed by farmers due to a lack of more refined information to inform an improved assumption. While water may have been physically available, the infrastructural, social, economic, and other barriers may inhibit one's ability to access and use that water to improve their livelihoods. The current model was refined based on findings from the survey to fill the knowledge gap regarding actual water access among the irrigation groups and actual rice planting patterns among farmers within these groups. Incorporation of this information and improvement of model assumptions allowed for the analysis to better reveal, demonstrate, and assess water availability and access among these groups under varying scenarios. Because these modifications were reliant on the survey results, they are described in detail in Section 3.3.

This analysis explores a modification of these scenarios based on the new information provided by the survey results. The aim of these new scenarios was to assess more realistic cropping patterns based on new knowledge and an understanding of how changes to water access representation as described in the previous section impacted the modeling results. The six modified scenarios assessed in this analysis are shown in Table 6 and were made up of combinations of three variables: the rice crop schedule, prioritizing different demands, and irrigation access. Each of these variables is described in more detail below.

Table 6. Scenarios implemented in the WEAP model after the survey results.

\begin{tabular}{|c|c|c|c|}
\hline Scenario Name & Rice Crop Schedule & Prioritize Different Demands & Irrigation Access \\
\hline S1: Baseline & Baseline & \multirow{2}{*}{$\begin{array}{l}\text { During shortages, ensured supply } \\
\text { to irrigation as a priority; no flow } \\
\text { requirement implemented }\end{array}$} & \multirow{3}{*}{$\begin{array}{l}\text { Assumed equal access } \\
\text { across groups }\end{array}$} \\
\hline S2: $\operatorname{ICS}^{1}$ & \multirow{2}{*}{$\begin{array}{l}\text { Groups } 1,2 \text {, and } 5 \text { grew wet } \\
\text { season, early wet season, and } \\
\text { dry season rice; all other } \\
\text { groups remained as in } \\
\text { the baseline }\end{array}$} & & \\
\hline S3: ICS + FR_Q95 ${ }^{1}$ & & $\begin{array}{l}\text { During shortages, ensured } 95 \\
\text { percentile flow downstream of } \\
\text { irrigation diversions as a priority }\end{array}$ & \\
\hline S4: Baseline + MDPA ${ }^{1}$ & Baseline & \multirow{2}{*}{$\begin{array}{l}\text { During shortages, ensured supply } \\
\text { to irrigation as a priority; no flow } \\
\text { requirement implemented }\end{array}$} & Represented poverty \\
\hline S5: ICS + MDPA ${ }^{1}$ & \multirow{2}{*}{$\begin{array}{l}\text { Groups } 1,2 \text {, and } 5 \text { grew wet } \\
\text { season, early wet season, and } \\
\text { dry season rice; all other } \\
\text { groups remained as in } \\
\text { the baseline }\end{array}$} & & $\begin{array}{l}\text { survey-based inequity in } \\
\text { access across groups }\end{array}$ \\
\hline S6: ICS + FR_Q95 + MDPA ${ }^{1}$ & & $\begin{array}{l}\text { During shortages, ensured } 95 \\
\text { percentile flow downstream of } \\
\text { irrigation diversions as a priority }\end{array}$ & \\
\hline
\end{tabular}

${ }^{1}$ ICS-increase crop schedule; FR_Q95-flow requirement at Q95; MDPA-inequity represented in the model.

\section{Results}

The results are presented in three subsections: (1) summary of the literature and the interviews, (2) survey indicators of multidimensional poverty in connection to water resources and a wealth index analysis, and (3) WEAP model changes and results.

\subsection{Summary of Literature Review and Key Informant Interviews}

The literature review and KIIs highlighted the challenges in social hydrology research in water resources management at the watershed level. Some of the findings from the literature review was included in the introduction of this paper. The sections below summarize the key challenges identified: (i) the integration and coordination of decisions across scales in watershed governance; (ii) creating the capacity and agency of local-level institutions, and (iii) location-based inequality in water access within the boundaries of a watershed. A section on gender inequality aspects was also included. 


\subsubsection{Lack of Integration of Policies across Scales Could Increase Inequalities}

Cambodia's economic development policies, which are premised on commercialized agriculture and privatized natural resources, have affected access to water resources and reshaped the livelihood options of local communities, particularly of the poor and women. For example, water concessions to large-scale and private commercial fisheries deprive local communities, particularly poor subsistent and women fishers, from accessing their traditional fishing grounds [52,67]. To fulfill the country's ambition of becoming one of the leading rice exporters, the Cambodian government has invested in the construction of many large-scale irrigation schemes in the upper part of Tonle Sap basin and granted land concessions to private agribusinesses in the flood plains. This benefits private agriinvestors, while many local communities have lost their traditional livelihood resources, such as wetlands for floating rice and grazing grounds for cattle [52]. Furthermore, the benefits of irrigation schemes are not distributed evenly among farmers. For instance, the schemes in the Stung Chinit watershed serve small areas in the basin (Figure 4, left). Commercialized agriculture and the privatization of natural resources in indigenous ethnic groups have eroded the traditional equitable decision-making systems and control over resources, labor exchange practices, and social solidarity that have been critical resources for women and the poor $[68,69]$.

3.1.2. Competing Uses of Water Resources for Energy, Agriculture, and Fishery Compromise Local Food Security and Entrench Inequality

Cambodia aspires to export electricity from hydropower [20]. The upstream construction of large-scale hydropower dams on the Mekong River and its tributaries has caused negative effects on the ecosystems and livelihoods of communities living on the Tonle Sap, potentially fueling further conflicts over water and aquatic resources [52,70]. Furthermore, impacts and benefits of hydropower development are not distributed equally $[20,21,67]$. For example, urban populations have higher access to electricity $(97 \%)$ compared to rural populations (68\%) [20] and rural communities typically experience the brunt of impacts of hydropower development, as dams are typically located in rural areas. At the same time, they cannot afford the cost of electricity produced by the hydropower that has taken away their resources [21,71]. The construction of the Stung Chinit reservoir for irrigation has caused declines in fish resources that negatively affect fishing communities downstream, and the reservoir is not operated to regulate water during dry or rainy seasons, which could lead to intensified flooding [72].

\subsubsection{Relative Location in the Watershed and Irrigation Schemes Can Exacerbate Inequalities}

Discrepancies in water management between upstream and downstream parts of the watershed can lead to location-based social inequalities and poverty [62,63]. For example, upstream farmers use groundwater for farming and their domestic activities (in Sandan district). Midstream and downstream farmers have more access to surface water and fishing is observed mainly in the midstream (Santuk district) and downstream (Baray district) [73]. Flooding mostly affects people downstream, most severely with flash floods [61]. Proximity to canals determines access to water for those whose fields are located within an irrigation scheme. However, the water does not reliably reach those farms that are farther from the main canals and downstream along the canal from other farms [29]. Access also depends on capital. Farmers who have the financial means to pay for pumps can get groundwater for their farms, can pump water from the canals to their fields, or can build their own storage to reserve water for when is needed [17].

3.1.4. Inclusive Participation and Institutional Coordination Can Contribute to Sustainable Management

Decentralized water management needs to be reinforced with capacity building, participation, and coordination. The construction of canals and the creation of Farmer's Water User Communities (FWUCs) improved farmer's livelihoods for some, but not for all. 
Rice farmers with access to irrigation canals improved their livelihoods by planting rice earlier, more reliably, and in the dry season [72]. Farmers are organized around FWUCs, which are responsible for maintaining the canal systems located within their jurisdictions and for communicating with farmers, local leaders, and the Provincial Department of Water Resources and Meteorology (PDoWRAM) to ensure that farmers have access to water from the reservoirs when they need it. The management of reservoirs and canals provides fish with a habitat, which increases fish productivity [74]; however, the FWUCs serve a small area in the watershed and provide benefits only to those located closer to the canals, who have access to information about when water shortages occur. While proximity to canals can create inequality of water access, cooperation between upstream and downstream users could remedy location-based inequality. Instead, the lack of coordination causes shortages for users located at the end of the canals $[61-63,68,75]$.

\subsubsection{Lack of Inclusion Efforts in Institutionalized Water Management Further} Disadvantages Women

Cultural expectations for Khmer women, the main ethnic group in Cambodia, are to be gentle, obedient, and caring. This limits their active participation in the public domain [76,77]. Female household heads, who account for $20 \%$ of rural households, face more challenges in dealing with male-dominated authorities [78] and in accessing irrigation water [79]. While national economic policies on commercialized agricultural and privatized natural resources, coupled with the competing use of water resources, have increased social and gender inequality between and within regions, the decentralization in resource management, such as community fisheries management systems, and FWUCs has not changed the unequal power relations between women and men. For example, fisherwomen are further excluded in fish management committees because they are not considered principal fishers and their contribution/role is undervalued [19]. Similarly, the FWUCs are mostly run by men [74] - there are 12 FWUCs in the region and only one FWUC has a female lead. Furthermore, women have been instrumentalized in the discourse of decentralizing natural resource management. Even though women have increasingly been involved in traditionally male-dominated domains, such as the maintenance of water and sanitation facilities and community fisheries management due to increasing pressure from donor agencies [80,81], the insertion of women into such community-based institutions without dealing with social relationships and practices that determine unequal resource allocation has increased women's workload and does not benefit nor empower them.

\subsection{Survey Indicators and Wealth Index}

Data for the construction of indicators were obtained from the poverty, gender, and water household survey conducted at the Stung Chinit watershed during October 2019. The survey collected information from 812 households living in the watershed. The analysis was structured around the poverty MDPA dimensions for each water-use sector: drinking and domestic, rice production, fishing, and livestock. The indicators were estimated by considering the relative frequency of the answers for each question and for households located at each section of the watershed: upstream, midstream, and downstream. Table 4 includes the list of indicators used for each dimension and each water use sector.

The values of the indicators listed in Table 4 are shown in Figure 5 below. The graphic uses petal-shaped graphical objects to represent each of the MDPA dimensions as it is indicated in the top menu and corresponds to the description of the indicators in Table 4. The values of the indicators range from 0 (least desired value) to 1 (most desired value). The sizes of the petals correspond to the value of the indicator; smaller values are closer to 0 and larger values are closer to 1 . The colors of the petals relate to the values of the wealth index differences between the "richest" quintile and the "poorest" quintile. The MDPA petals are organized in columns for each sector: domestic, rice, fishing, and livestock. Each row corresponds to the location of the households in the watershed: upstream, midstream, and downstream. The sections below include a description of the indicator analysis for each sector and location. 
Multidimensional Poverty Indicators

Analysis of indicators related to the linkages between water and poverty concerning water access and use in the upstream, midstream, and downstream part of the watershed.
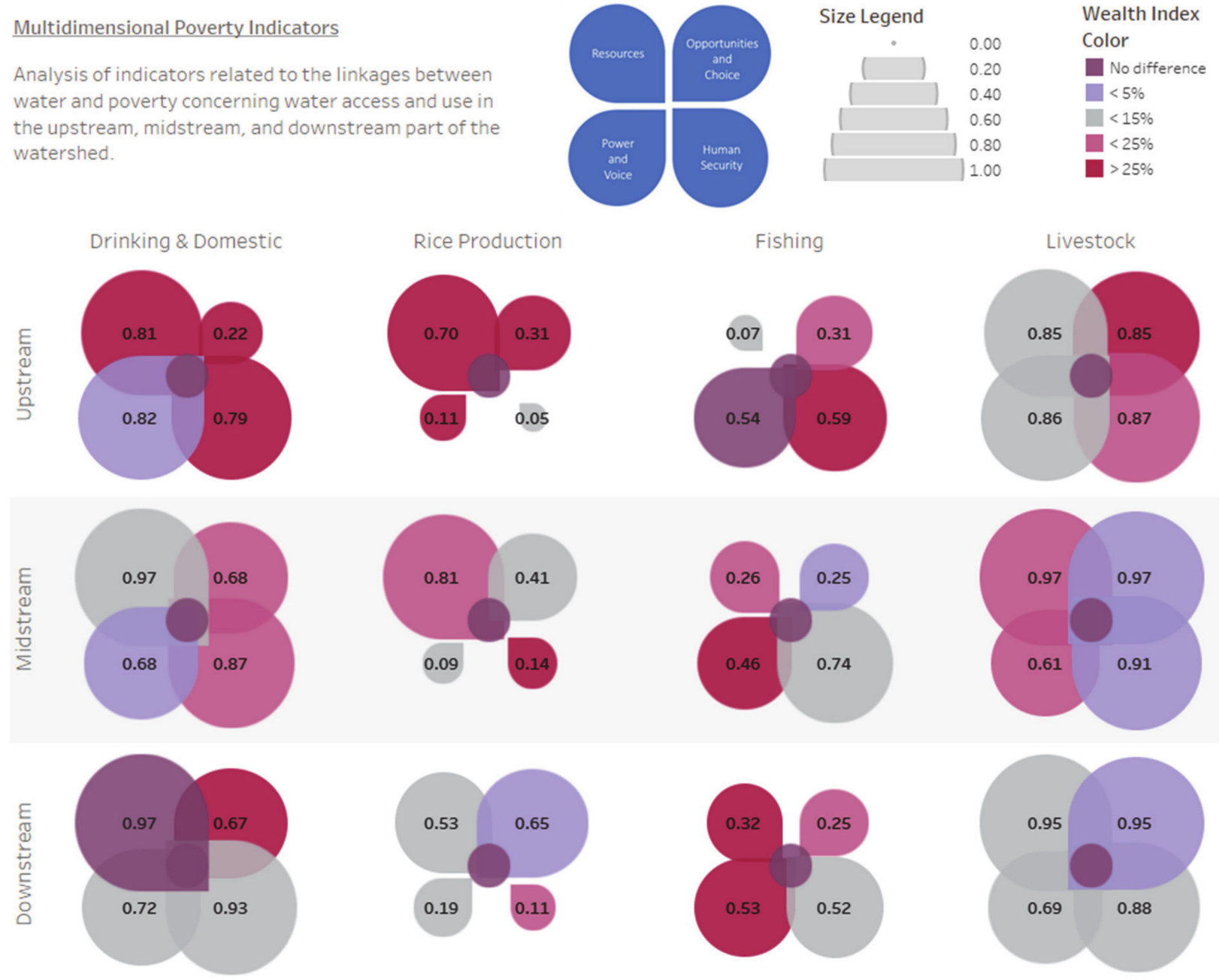

Figure 5. Graphical representation of the MDPA indicators described in Table 4 . The sizes of the petals correspond to the value of the indicator ranging from 0 (least desired values) and 1 (most desired values). Petal colors correspond to wealth index values differences between the "richest" quintile and the "poorest" quintile.

\subsubsection{Drinking and Domestic}

The results indicate that all parts of the watershed had access to some source of water; however, not all households had safe drinking water on their premises, which means that they needed to collect it. The indicator for households collecting water (O1) indicates the proportion of households who did not spend time collecting water or spent less than $30 \mathrm{~min}$. The value of this indicator for the upstream part of the watershed was 0.22 , meaning that $78 \%$ of the households spent more than 30 min collecting water, and that value was even lower for the poorest percentile (Figure 5). The values for this indicator of water collection time for midstream and downstream parts were 0.68 and 0.67 , respectively, meaning that close to $70 \%$ of the households spent no time or less than $30 \mathrm{~min}$.

Further analysis on water collection time was done to determine the individuals collecting the water in terms of gender and the specific locations of the household within the watershed (Figure 5). As indicated by O1, those in the upstream part of the watershed spent more time collecting water than elsewhere (also shown in Figure 6). Further analysis on who collected the water (Figure 7) indicates that, contrary to suggestions by key informant interviews and the literature, women were not the dominant group collecting water, and neither were children. This is an interesting finding that needs more examination. 


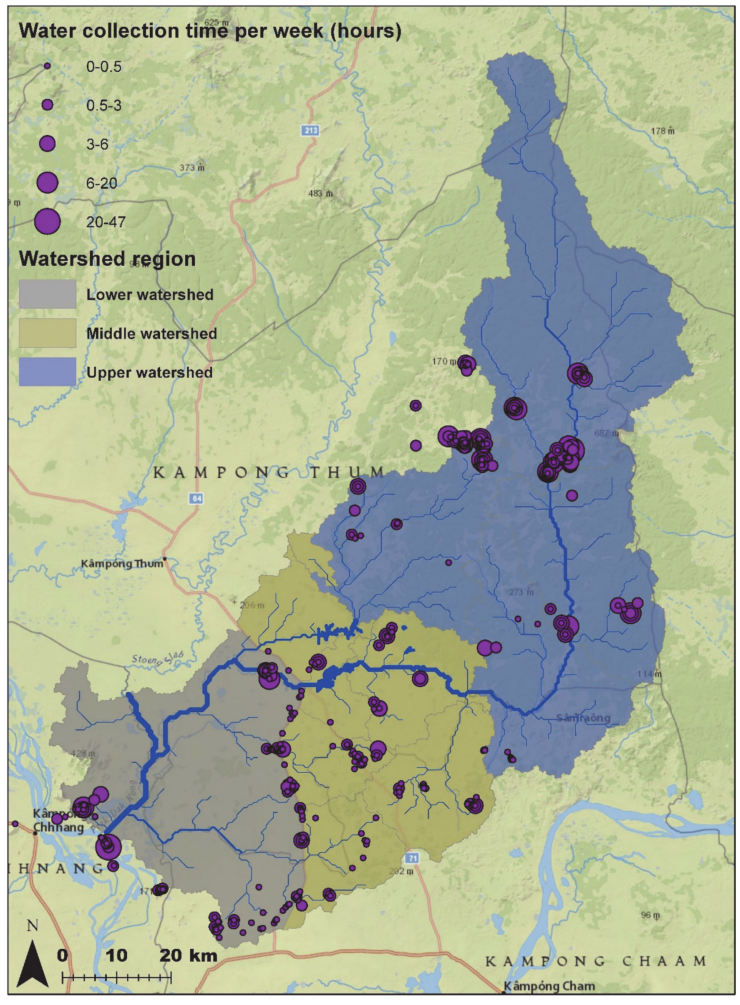

Figure 6. Map of the Stung Chinit watershed and number of hours per week households spent collecting water.

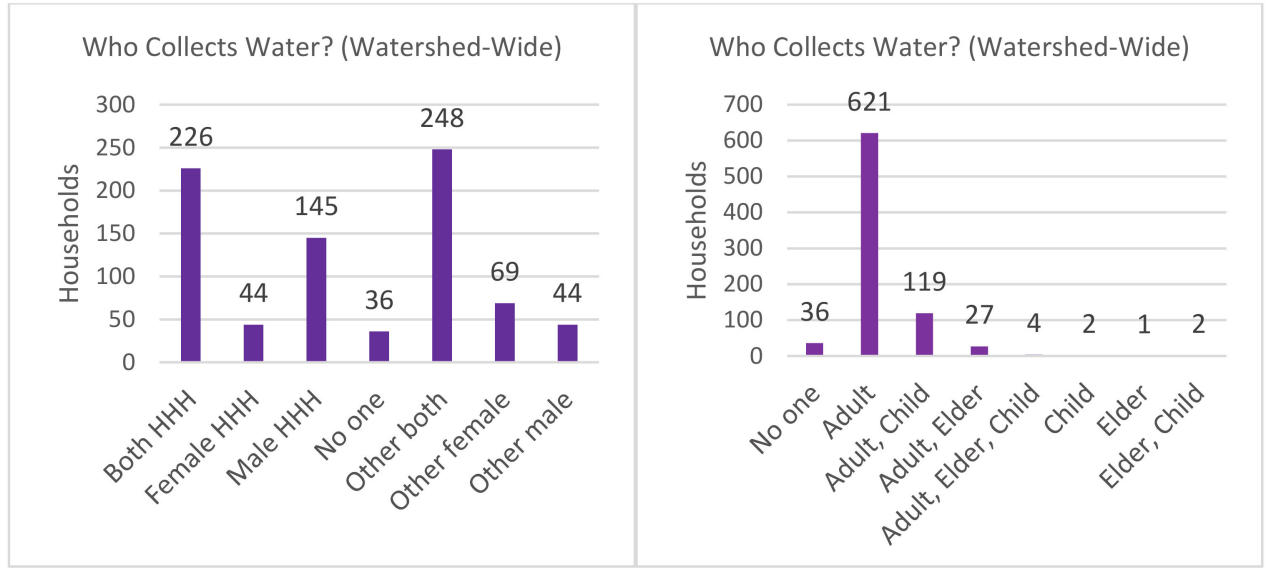

Figure 7. Household's responses to who was responsible for collecting and ensuring that there was enough water in the home for domestic use by gender group (left) and by age group (right). Both $\mathrm{HHH}$ indicates both household heads were selected, while Female $\mathrm{HHH}$ and Male $\mathrm{HHH}$ indicate female and male household heads, respectively. Other both means at least one person of each gender who were not both household heads were selected. Other female means one or more females who were not the household head were selected and other male means one or more males who were not the household head were selected.

\subsubsection{Rice Production}

Water availability for irrigation (R2) shows the percentage of those who had enough water among the households that irrigated rice. The downstream areas had the lowest values for $\mathrm{R} 2$ with 0.53 , followed by the upstream part with 0.70 and then the midstream with 0.81 . While values for rice irrigation availability was 0.70 upstream, indicators for available water for subsistence $(\mathrm{O} 2)$ was 0.31 . The greatest differences in the wealth index 
for most of the indicators for rice production were found upstream. In particular, indicators that related to having access to an FWUC (P2) showed a low percentage of households across the watershed, in particular in the mid and upstream portions (0.09 and 0.11, respectively). Furthermore, most households in the upstream region reported suffering from natural disasters that affected their agriculture in the last twelve months (H2).

\subsubsection{Fishing and Livestock}

Fishing, similar to rice, is a key socio-economic activity. Indicator $\mathrm{O} 3$ estimated that between 25 to $30 \%$ of the households depended on fishing. Out of these households, R3 estimated the percentage for which fish was caught for food provision only. This value was greater downstream (0.32), followed by midstream (0.26) and upstream (0.07), which emphasized the importance of fishing in people's diets and food security. Survey indicators for livestock access and use show that in all parts of the watershed, households depended on livestock and had enough water to support those activities.

\subsubsection{Gender Data Disaggregation for Gender Analysis}

Across the three domains of water use that the gender analysis focused on (i.e., domestic water supply, agriculture/irrigation, and fishing), the data indicate that male household heads had more decision-making power across all domains. However, participation in decision making at the community level was low across the areas. In terms of the domestic water supply, the key aspect of decision making was about investment in water supply infrastructure, as over half of the surveyed households reported making time and financial investment in improving their domestic water supply, with no significant difference between male-headed households and female-headed households. Thus, while male household heads dominated decision making regarding domestic water supply at the household level, the data show that decisions were often made in consultation with female partners of the household head and other female and male adults in the family. At the community level, there were few public meetings on issues around domestic water, which may have been because most domestic water sources were individual household investments (such as wells). Within irrigation and agriculture, women are particularly underrepresented in decision-making bodies, such as FWUCs. Furthermore, there was a gap in access to information regarding water supply between male and female household members. This was particularly evident in terms of irrigation water, where not only half of the FWUC participants reported not knowing the FWUC's irrigation scheduling and fees, but men were also reported to be the primary recipients of the information. With regard to fishing, there were significantly more female-headed households that reported catching fish for food supply as compared to male-headed households, which tended to also sell their fish. This may suggest that female-headed houses tended to retain less surplus to sell for income. In relation to this, female-headed households also experienced worse subsistence impacts due to the reduction in fish resources than male-headed households, with the data indicating more female-headed households are not getting enough fish for food, in contrast with male-headed households.

\subsection{WEAP Model Refinements and Results}

The survey results were used to refine the model and analysis developed in [29], specifically the representation of rice planting and irrigation. This section shows the survey results that informed the refinement of the model, as well as the results for the refined model.

\subsubsection{Refinement of Irrigation Water Access}

The survey results regarding water access for irrigation were used to improve the representation of rice irrigation practices in the model by reflecting existing inequalities on the ground. Because the model focused on the irrigation system supported by the Stung Chinit and Krasaing reservoirs [29], only survey responses from households that used that 
system or were nearby to that system and therefore might have had the potential to use it were used to improve the model's representation. The household selection was influenced by the results of two survey questions: "Do you use irrigation canals in the dry season?" and "Does an FWUC exist in your community?" as well as geographical information. Figure 8 shows the spatial representation of these responses and a $15 \mathrm{~km}$ buffer from the existing canal system. All households within the $15 \mathrm{~km}$ buffer were included and assigned to the nearest irrigation group (Figure 8, right). This buffer was selected based on three factors: (1) Households may not be located directly adjacent to the household's fields; therefore $15 \mathrm{~km}$ was a reasonable distance to assume that someone may travel to their fields. (2) This buffer captured most houses that stated they used irrigation canals in the dry season (Figure 8, left). Households farther than $15 \mathrm{~km}$ from the canal system did state that they used canals for irrigation in the dry season, but it was assumed that the households in the lowest part of the watershed used canals directly off the river outside the canal system under study (Figure 8, left). (3) This buffer captured most houses that stated an FWUC exists in their community (Figure 8, center). Some households outside of the $15 \mathrm{~km}$ buffer indicated that FWUCs did exist in their village or community, but similarly, due to the clustered pattern of the responses, it was assumed that those outside of the buffer were referring to FWUCs that operated different systems than the one being studied (Figure 8, center).
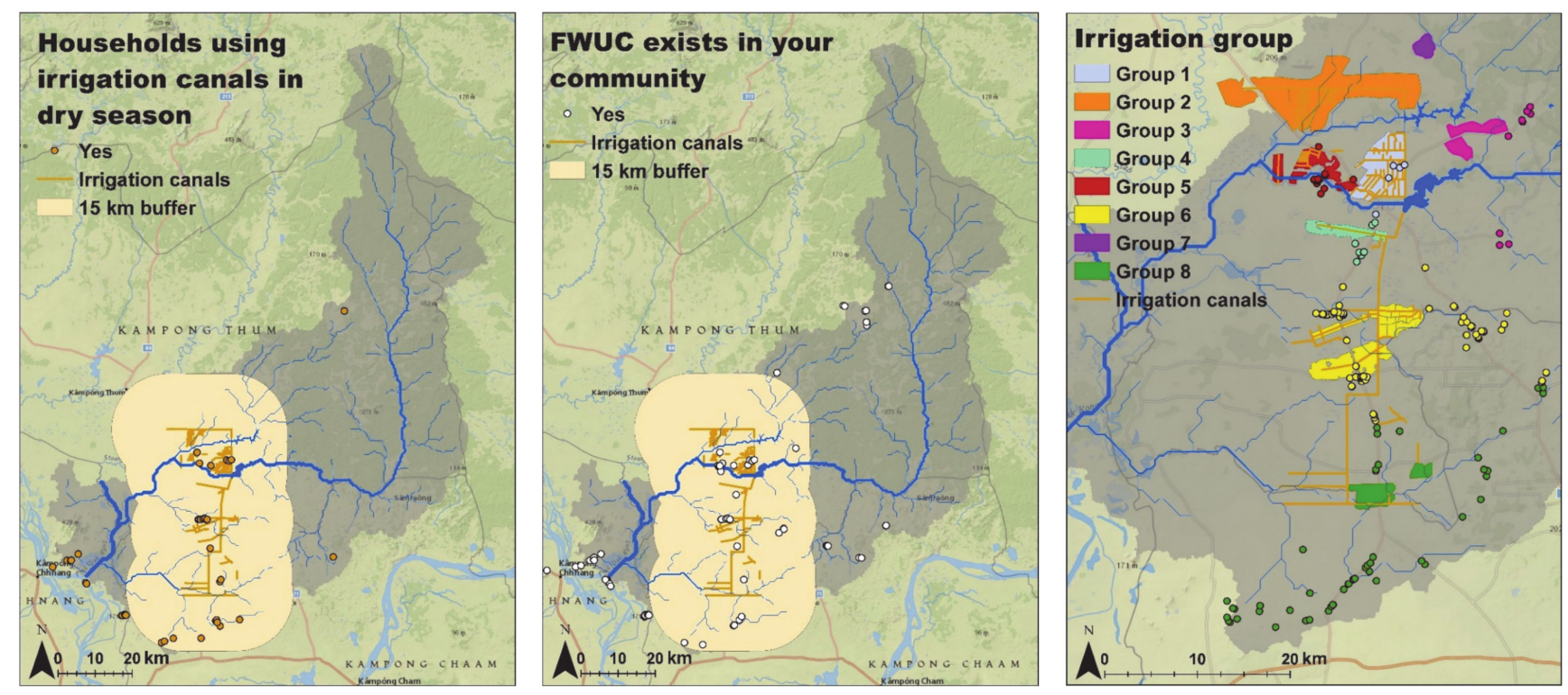

Figure 8. Map of the Stung Chinit watershed with irrigation canals, a $15 \mathrm{~km}$ buffer around irrigation canals, the households that responded that they used canals for irrigation in the dry season ((left), question 93 and 94), the households that responded that an FWUC did exist in their village or community (center, question 122), and the households within the buffer assigned to the nearest irrigation group (right).

Despite previous findings from the literature and KIIs, the gender of the household head did not appear to play a large role in the access to different source types (Figure 9); therefore, the model was not refined to consider the gender of household head in regard to irrigation water access. However, survey results show that location largely determined the irrigation access: for those households that did use canals and were located within the $15 \mathrm{~km}$ buffer, the farther the household was from the reservoirs (groups 6 and 8, Figure 10), the less likely they were to have enough water (Figure 10). Across the year, households closest to groups 6 and 8 reported having shortages in irrigation water in most months of the year, while the other groups reported shortages in fewer months or not at all (Figure 10). Most households who irrigated in closest proximity to group 8 experienced irrigation issues, 
along with a wide variety and combination of issues (Figure 11). Few households who used canals closest to groups 1 and 5 experienced issues (Figures 10 and 11).

Prior to the survey analysis, it was assumed that all irrigation groups received water equitably because better information was not available to support another assumption. However, inequity in water access between the groups was evident in the survey analysis. To reflect this new understanding, the model was modified so that when there were shortages, groups 3 and 7 could take water first because they were farther upstream, then water was given to groups 1,2 , and 5 equally (these groups were closest to the reservoir system; based on field visits to group 2, it was assumed to operate well and therefore farmers were likely to have sufficient water), then to group 4, then group 6, then lastly, group 8 (see Figure 4 for the location of the groups). All other rules regarding irrigation in the model remained as described in [29].

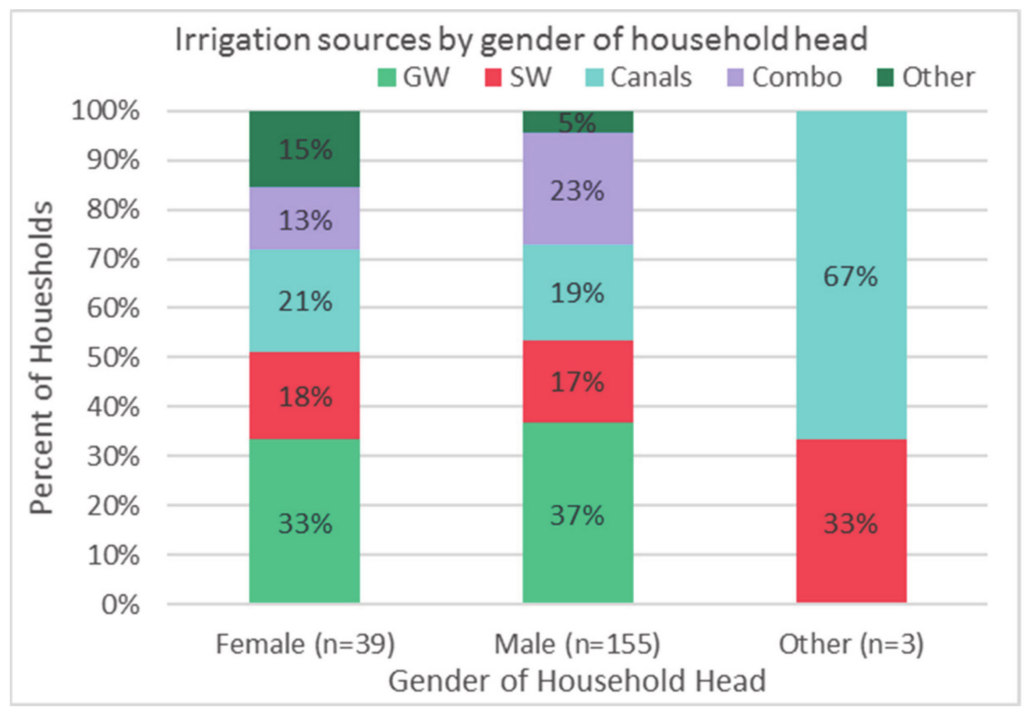

Figure 9. Percentage of households who used various irrigation source types by gender of the household head. GW refers to groundwater, SW refers to surface water, Combo refers to a combination of 2 or more source types. Dry season and wet season sources are combined based on responses from questions 93 and 94.

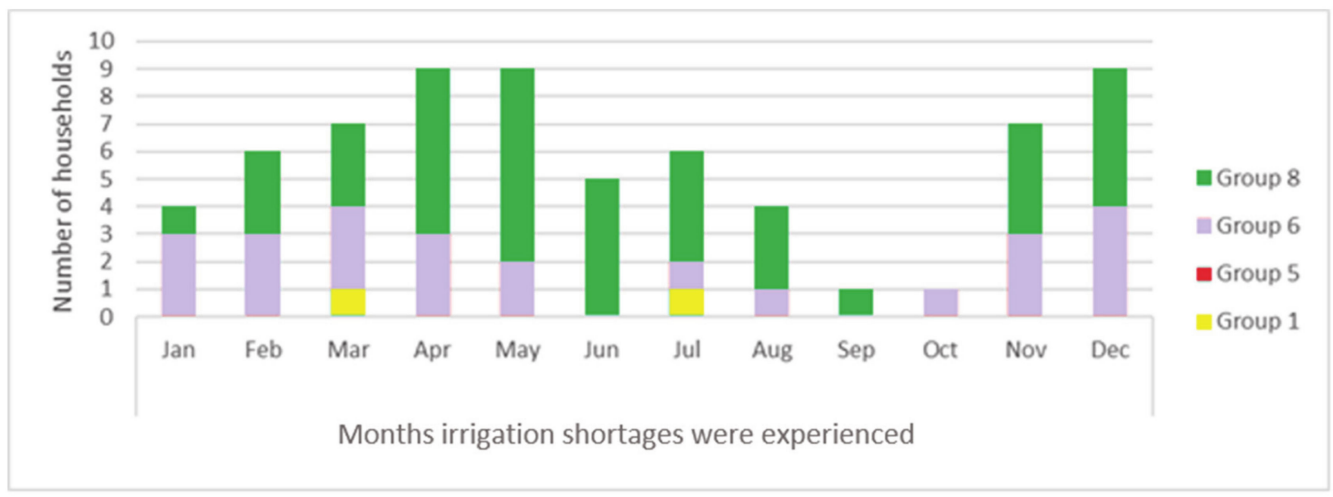

Figure 10. Months where households within $15 \mathrm{~km}$ of irrigation canals, who stated that they used canals for irrigation (question 93 and 94) experienced shortages in irrigation supply in the last year (based on responses to question 104). The groups refer to the closest irrigation group to the household. The irrigation groups are shown in Figure 3. 


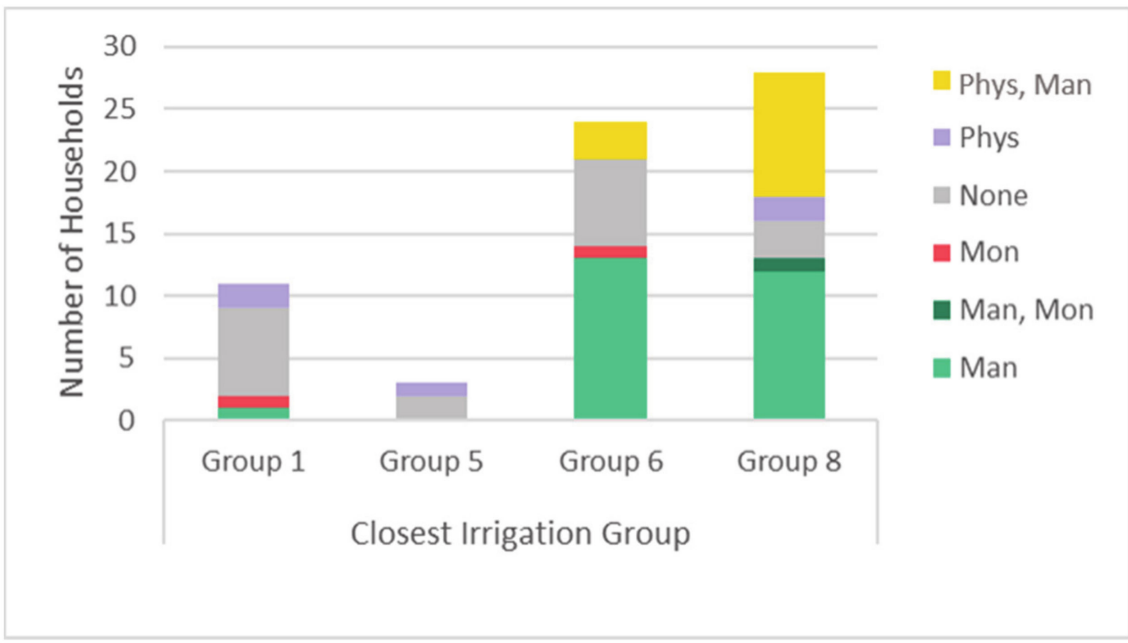

Figure 11. Irrigation issues experienced in the last 12 months (responses to survey question 105) by households within $15 \mathrm{~km}$ of the irrigation canals that stated they used canals for irrigation in questions 93 or 94 . The groups refer to the closest irrigation group to the household. The irrigation groups are shown in Figure 4. "Phys" means physical issues, which correspond to the responses "my field is too far from the canal," "not enough tertiary canals," or "my field is at too high an elevation." "Man" means management issues, which correspond to the responses "the upstream people take more water than they should, so I don't get any," "there is not enough water late in the season," "there is not enough water early in the season," "the quantity of water overall is too little," or "the timing of water does not suit my needs." "Mon" indicates monetary issues, which correspond to the responses "I cannot afford the water/FWUC fees" and "I cannot afford to pump the water onto my fields."

\subsubsection{Refinement of Rice Cropping and Modeled Scenarios}

The analysis presented in [29] shows the trade-offs between supplying water for rice expansion and maintaining river flows for fish. This previous work explored scenarios that combined considerations of climate change, different rice crop schedules, increasing irrigated area, and prioritizing different demands for downstream flow requirements [29], Table 6.

While it was known that farmers may grow rice once, twice, three, or four times per year, prior to the survey analysis, it was not well understood what proportion of farmers practiced these various crop schedules. Therefore, in the baseline scenario of [29], all groups grew rice once per year, and in all subsequent scenarios regarding increasing crop schedules, the increases in plantings were applied uniformly across all groups (all groups grew twice per year, all grew three times per year, etc.). Figure 12 shows the percentages of households closest to each group (using the same subset of households as described in the previous section) that used canals for irrigation and grew rice once, twice, and three times per year, as found through the survey results. Across all groups, most households were growing rice twice per year, group 5 had the greatest proportion of households growing rice three times per year, and group 8 had the greatest proportion of households growing rice once per year (Figure 12). No households reported growing rice four times per year. To make this set of scenarios more realistic, these percentages were applied to the area of groups in the model to areas that grew rice once, twice, and three times per year in the baseline scenario. For groups that were not represented by the survey, these assumptions were made: all areas in groups 7 and 3 only planted once per year, group 2 was equal to the distribution for group 1, and group 4 was equal to the distribution of group 6 . 


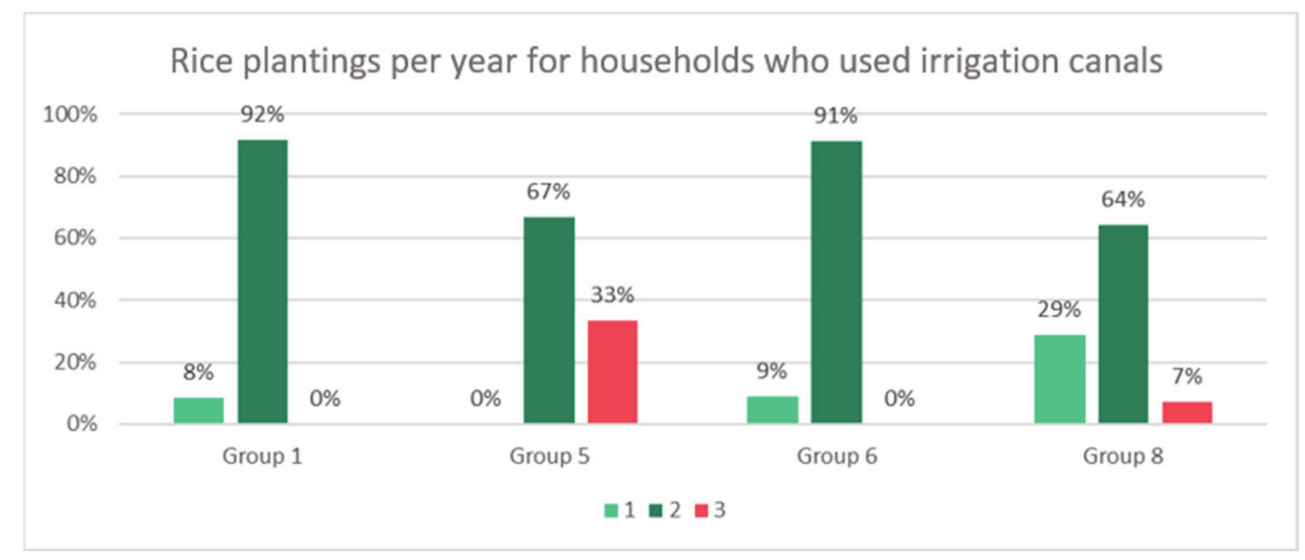

Figure 12. Number of times per year that households within $15 \mathrm{~km}$ of each irrigation group who used canals for irrigation (questions 94 and 95) grew rice (based on responses from question 74).

An increased rice crop schedule was considered in these scenarios based on the improved understanding of current practices (Figure 12) and the new understanding that groups upstream and closest to the reservoirs had more reliable irrigation access than groups farther from the reservoirs (as described in the previous section). In this crop pattern, the entire area of only groups 1,2, and 5 grew rice three times per year, and the distribution of rice cropping within the other groups remained as shown in Figure 12 (S2, S3, S5, and S6; Table 6).

The consideration for prioritizing different demands remained the same in these scenarios as in the previous work, where some scenarios included no flow requirement and irrigation demands were prioritized (S1, S2, S4, and S5; Table 6) and ones where a streamflow requirement of the 95th percentile flow (Q95) for each month of the year was prioritized downstream (S3 and S6; Table 6).

All scenarios in this analysis were simulated with the historical climate repeated over years 2019-2047.

\subsubsection{WEAP Model Output Comparison}

A major goal in this analysis was to investigate the differences in model results when all irrigation groups' accessed water equally (an assumption based on information without social factors gathered from the household survey) and when the inequity that was seen in the household survey was reflected in the model construction, and therefore, how water management decisions could be misled by modeling results that neglected social factors. The results show that the incorporation of social factors into the hydrological model led to different results for irrigation coverage by irrigation group. Figure 13 shows violin graphs to represent the average annual percent irrigation coverage for the irrigation groups under each scenario and water year type. The violin graphics were structured in three columns according to the year type-dry, average, and wet-and in two rows. The first row corresponded to the scenarios without the incorporation of the poverty analysis (S1 to S3 based on Table 6). The second row shows the results with the incorporation of the poverty analysis (S4 to S6 from Table 6). In dry and average years, the difference between the two sets of scenarios was particularly apparent. Specifically, the high priority groups ( 3 and 7), followed by the next priority groups (1,2, and 5), experienced much higher coverage than the lowest priority groups $(4,6$, and 8$)$ in dry and average years when these considerations were incorporated ("poverty and gender $=$ true"). In the first row (S1, S2, S3), the differences in coverage between the irrigation groups were much less pronounced, producing violin plots that were denser and where the high priority groups from the other scenarios (S4, S5, S6) experienced more shortages. However, the differences between coverage in the original hydrologic model and the model modified with social factors were much less pronounced for wet years. Notably, the second priority 
group $(1,2,5)$ did relatively well with respect to the lowest priority group $(4,6,8)$ in the irrigation expansion without flow requirement scenario (S5) during dry years, whereas those irrigation groups performed much more closely to the lowest priority groups for the baseline (S4) and irrigation expansion with flow requirement (S6) in dry years. Of all the scenarios tested, the irrigation expansion with flow requirement scenario (S6) seemed to have the largest change in coverage behavior for all irrigation groups when considering social factors as opposed to the coverage results for the model that did not consider social factors in both dry and average year-types.
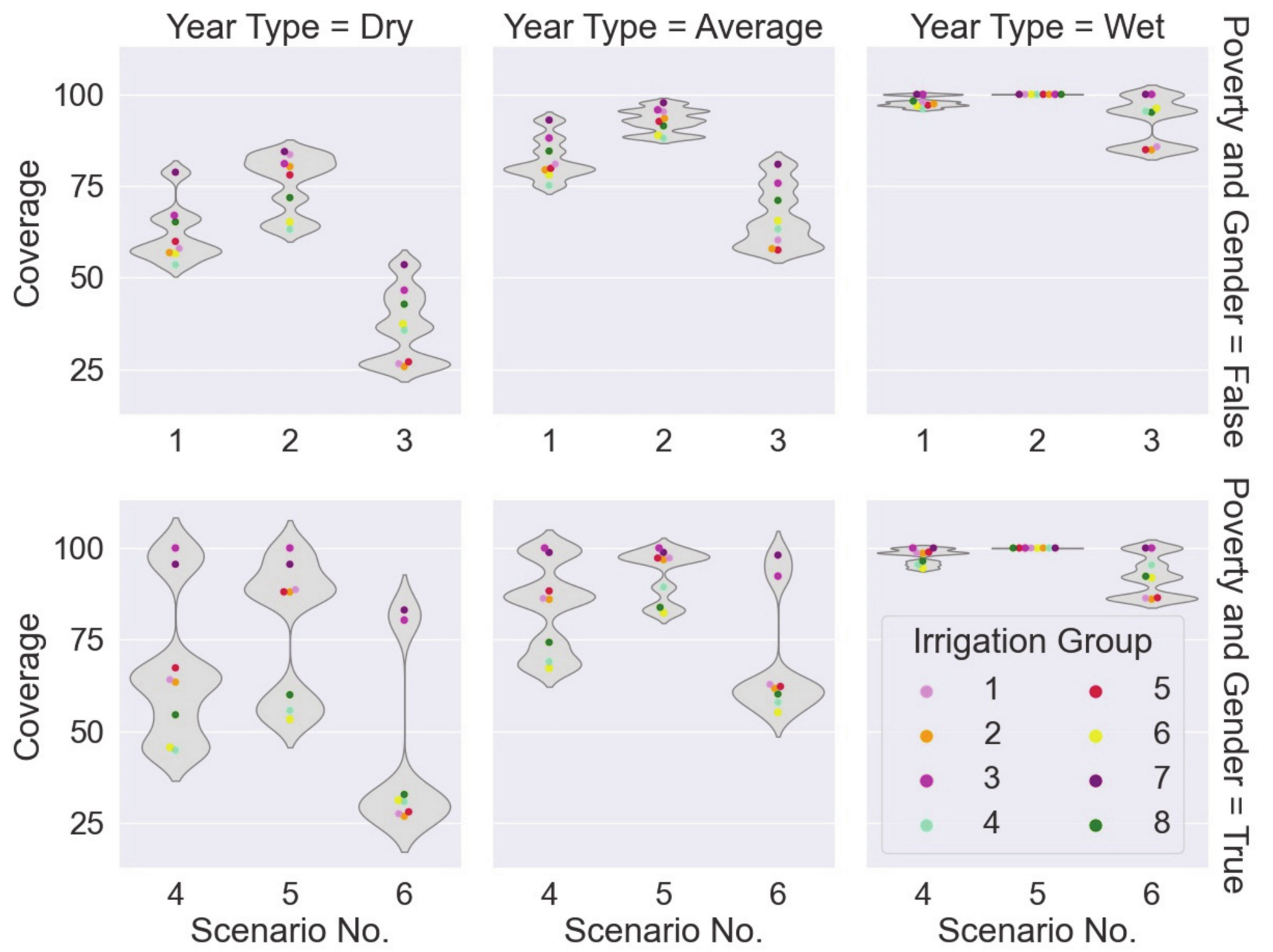

Figure 13. Violin plots of the average percent irrigation coverage during all years when looking at different year types (dry, average, and wet) and with or without poverty and gender considerations in the model structure. The data was separated by scenario (1-6 as described in Table 6) and irrigation group (1-8, as shown in Figure 4).

\section{Discussion}

The scale in which policies were developed and implemented was mismatched from the challenges of the people and ecosystems that are affected. National-level decisions aimed at improving macroeconomic indicators exacerbated poverty at local levels. Poverty realities were affected by the relative location of communities within a watershed, which emphasized the need for inclusive participation and joint consultation at the local level and coordination between people within a watershed and with the national government. Aspects of the decision scale, relative location, and coordination created inequalities in water access for domestic use, rice production, and fish conservation in the Stung Chinit watershed.

Results on drinking and domestic water use indicate that communities in the upstream part of the watershed had limited access to water in their homes, had food shortages, and 
spent a significant amount of time collecting water. The upper watershed should be targeted for interventions to provide safe access to domestic water supplies that result in making this time available for other purposes. Gender analysis of the survey data shows that the gender of the household head was also a variable that was linked to water access and water sources. For example, across the locations, the numbers of male-headed households experiencing water shortages were higher than those of female-headed households.

The information gap between genders suggests that while entities such as FWUCs expected farmers to be aware of information on irrigation and bear the responsibility to farm accordingly, there was limited consideration on how that information may not be equally accessible by male and female irrigators.

Overall, there are key aspects of the survey that could be clarified through qualitative methods to bolster the assessment of gender aspects of water-related access. Additionally, quantitative data are limited in capturing the dynamics of decision making (e.g., how decision making is negotiated at the household and community level). Thus, data on decision making can be further substantiated with qualitative methods to better understand how personal experiences and household dynamics can provide a more holistic picture to the survey data.

Climate change adaptation strategies for rice production, as well as water management actions, are needed upstream where most of the households suffered from natural disasters on agriculture in the last twelve months and there was low participation in local water management, i.e., the FWUCs. The other parts of the watershed would also benefit from more participation in the FWUCs and strategies to prevent and mitigate natural disasters affecting rice production.

Models are often not developed with household or community level input, but rather with national-level or coarse-level datasets. It is evident that without the poverty and gender survey considerations, the Stung Chinit model was largely underrepresenting shortages in the irrigation supply seen by groups farthest from the irrigation system. The previous study suggested that there was sufficient water in the modeled irrigation system to expand the irrigated area by $10 \%$, grow rice twice per year, and protect downstream flows under climate change [3]. However, this study shows that while this water may be available, it was not necessarily accessible to all. Without adding this aspect of reality into the model, new irrigation systems, changes to existing systems, or other policies or infrastructure that may be assessed in the model would not accurately represent those who benefit and those who do not. This could lead to reinforcing existing inequalities. It is often those who do not have a voice or are not included in technical discussions or policy development who experience these inequities and do not have their experiences represented in decision-making tools.

Additionally, the model results suggest that collaboration and coordination between the groups, and therefore the FWUCs, not just within the groups/FWUCs, should be a priority. The Stung Chinit FWUC tended to be successful in supplying water to their members; however, this was sometimes at the expense of other groups farther down the canal system, such as groups 6 and 8. Staggering planting times, when irrigation demand is the greatest, between the groups may allow for more water for everyone. Coordination of rice plantings and who plants once, twice, or three times per year should also be planned among all groups collaboratively because planting is the more water-intensive period, and therefore when shortages occur.

There were many aspects of the watershed that were reflected in the survey data that were still not well represented in the model, for example, irrigation demands outside of the irrigation scheme that was studied. For a better representation of these areas, a complete understanding of the irrigation demands of the system should be improved as more information becomes available. Additionally, access to water is only one aspect of agriculture. Many households indicated the importance of agrochemical use, such as fertilizer and pesticides, which should be further investigated, both to better understand the impact of these products on yield, as well as on the environment and water quality. While 
water access is still a challenge for many in the watershed, coping strategies when there are shortages is another major aspect where poverty and water intersect. Understanding who can still maintain their crops during shortages and who cannot should be better understood to develop a more complete picture of the interlinkages between water for agriculture and poverty, particularly under climate change. For this analysis, scenarios of climate change were not considered but should be in future work.

These findings point to several potential policy linkages or interventions. The model points to the opportunity to engage with the Ministry of Water Resources and Meteorology; the Ministry of Agriculture, Forestry, and Fisheries; and the Ministry of the Environment to inform the model's findings, particularly in terms of overall access to water resources and illuminate the influence of issues such as poverty, gender, location, and information access. This study can inform the National Strategic Development Plan's Strategy for Agriculture and Water to achieve their goals around water resources development and management, poverty reduction, and economic growth for households in the Stung Chinit watershed.

The Ministry of Water Resources and Meteorology; the Ministry of Agriculture, Forestry and Fisheries; and the Ministry of the Environment institute planned capacity strengthening and information sharing interventions with gender mainstreaming in the agricultural sector, water resources, and climate change under the coordination and direction of the Ministry of Women's Affairs.

This ministry has just recently endorsed Neary Rattanak (2019-2023) for Gender Equality and the Empowerment of Women in Cambodia [82]. This five-year strategic plan, together with the National Strategic Plan on Gender and Climate Change 2014-2023, Master Plan for Gender and Climate Change (2018-2030), and Action Plan on Gender and Climate Change 2019-2023, as well as other national guidelines for gender mainstreaming $[83,84]$ in these prioritized sectors, will be a roadmap for the development of programs that help to address the needs of women and other vulnerable groups [82,85]. For example, addressing apparent information gaps between men and women regarding FUWC operations and schedules could be one of the focus areas.

Finally, it is evident from this analysis that the benefits of water supply are not equally shared among all areas of the watershed such that proximity to a main canal or up/downstream can substantially impact a household's access to water. Given the connection of water access and climate change vulnerability to poverty reduction, it would be important to evaluate whether policies, such as the Law on Water Resources Management (2007) and the National Water Resources Policy (2004), have any specific focus or mechanisms directed at addressing these issues of unequal access.

\section{Conclusions}

The connection and dependency of watersheds and human wellbeing are due to the watersheds' provision of water resources that are essential for human life, agricultural production, fish habitat, transportation, and other social and economic activities. Hydrological processes in a watershed impact peoples' lives, as annual cycles of dry and wet seasons affect peoples' annual socio-economic activities and traditions.

This study evidenced the strong linkages that exist between sustainable water resources management objectives and poverty reduction efforts. Model results show that by linking qualitative and quantitative analyses of social and hydrological information, a better representation of the location-based inequalities within a watershed can be achieved. The qualitative and indicator analysis presented a broader understanding of the socialhydrological linkages. Having this broader understanding of the social inequality implications in connection to water access can help to formulate policies that ensure water security at the local level and support poverty reduction at the national level.

Inequalities that lead to poverty, such as the water distribution challenges within the Stung Chinit irrigation system, with those most downstream receiving the least water, are known [29,61,62,73]. While this information is known, it has not been factored into basin-level modeling work or watershed-level plans. This is a critical issue for ensuring 
the sustainable management of water resources and poverty reduction. In this case study, we demonstrated how to factor in small-scale distribution inequalities and challenges into watershed level analysis to give decision makers at the watershed scale the knowledge and the tools required to address these inequalities.

Supplementary Materials: The following are available online at https:/ /www.mdpi.com/article/10 .3390/w13131848/s1, Table S1: Research design, Document S2: Key informant interview questions, Document S3: Frequency tables for survey questions.

Author Contributions: The conceptualization and funding acquisition of this work were conducted by L.F., B.P.R., M.L. and A.H.-L., with supervision and project administration provided by L.F. Survey data curation and analysis for poverty indicators was conducted by C.S., A.L., P.U. and S.E. Gender analysis from the survey data was conducted by J.Y.-C.H. and H.N. Wealth index calculations and analysis were conducted by S.E., A.L. and L.V. Model modifications and analysis was conducted by S.B. Visualization of model results was conducted by M.R.M. The writing-original draft preparation of this article was conducted by L.F., S.B. and M.R.M. and the writing-review and editing was conducted by L.F., M.R.M., S.B., H.N., J.Y.-C.H., C.S., P.U. and B.P.R. All authors have read and agreed to the published version of the manuscript.

Funding: This research was partly funded by Sida core support to the Stockholm Environment Institute and partly by The Asia Foundation.

Institutional Review Board Statement: The study was conducted with verbal consent during the survey and interview process. The surveys follow the ethical protocols from the Kandence survey company led by Sunil Pillai spillai@kandence.com.

Informed Consent Statement: Informed consent was obtained from all subjects involved in the study.

Data Availability Statement: The data that support the findings of this study are available on request from the corresponding author.

Acknowledgments: We would like to thank our project partners and stakeholders who supported us with the key informant interviews, in particular, the local Sustainable Water Partnership team-Min Bunnara, Sen Kimtheng, Chourn Phyroum, and Sok Soleak. Thank you to the Winrock International team-Liz Kendall, Robert O'Sullivan, and Eric Viala—for supporting this project. Thanks go to Natalia Biskupska for her financial management with local partners the SEI Asia Center and Sunil Pillai from Kandence International for executing the survey. Thanks go to Marie Jürisoo for her support with contractual aspects as the SEI HQ Operations Director. Thanks go to the SEI-US water program for support in the preparation of this article.

Conflicts of Interest: The authors declare no conflict of interest.

\section{References}

1. Cosgrove, W.J.; Loucks, D.P. Water management: Current and future challenges and research directions: Water management research challenges. Water Resour. Res. 2015, 51, 4823-4839. [CrossRef]

2. Kundzewicz, Z.W.; Krysanova, V.; Benestad, R.E.; Hov, Ø.; Piniewski, M.; Otto, I.M. Uncertainty in climate change impacts on water resources. Environ. Sci. Policy 2018, 79, 1-8. [CrossRef]

3. Gleick, P.H. The human right to water. Water Policy 1998, 1, 487-503. [CrossRef]

4. Adger, W.N.; Huq, S.; Brown, K.; Conway, D.; Hulme, M. Adaptation to climate change in the developing world. Prog. Dev. Stud. 2003, 3, 179-195. [CrossRef]

5. Kang, Y.; Khan, S.; Ma, X. Climate change impacts on crop yield, crop water productivity and food security-A review. Prog. Nat. Sci. 2009, 19, 1665-1674. [CrossRef]

6. Sabo, J.L.; Ruhi, A.; Holtgrieve, G.W.; Elliott, V.; Arias, M.E.; Ngor, P.B.; Nam, S. Designing river flows to improve food security futures in the Lower Mekong Basin. Science 2017, 358. [CrossRef]

7. SIDA. Perspectives on Poverty. Elanders. 2002. Available online: https://www.scribd.com/document/213324931/Perspectiveson-Poverty (accessed on 20 February 2018).

8. SIDA. Multidimensional Poverty Analysis (MDPA). 2017. Available online: https://www.sida.se/contentassets / 4 ecfd4234864 4d32abbfdccbed6f15c0/mdpa_poverty_analysis.pdf (accessed on 21 February 2018).

9. Cobbinah, P.B.; Black, R.; Thwaites, R. Dynamics of Poverty in Developing Countries: Review of Poverty Reduction Approaches. J. Sustain. Dev. 2013, 6. [CrossRef] 
10. Douglas, M.M.; Jackson, S.; Canham, C.A.; Laborde, S.; Beesley, L.; Kennard, M.J.; Pusey, B.J.; Loomes, R.; Setterfield, S.A. Conceptualizing Hydro-socio-ecological Relationships to Enable More Integrated and Inclusive Water Allocation Planning. One Earth 2019, 1, 361-373. [CrossRef]

11. Forni, L.G.; Medellín-Azuara, J.; Tansey, M.; Young, C.; Purkey, D.; Howitt, R. Integrating complex economic and hydrologic planning models: An application for drought under climate change analysis. Water Resour. Econ. 2016. [CrossRef]

12. Myers, R.; Hansen, C.P. Revisiting A Theory of Access: A review. Soc. Nat. Resour. 2020, 33, 146-166. [CrossRef]

13. Whiteley, J.M.; Ingram, H.; Perry, R.W. (Eds.) Water, Place, and Equity; The MIT Press: Oxford, MA, USA, 2008. [CrossRef]

14. Kemp-Benedict, E.; Cook, S.; Allen, S.L.; Vosti, S.; Lemoalle, J.; Giordano, M.; Ward, J.; Kaczan, D. Connections between poverty, water and agriculture: Evidence from 10 river basins. Water Int. 2011, 36, 125-140. [CrossRef]

15. Lustig, N. Multidimensional indices of achievements and poverty: What do we gain and what do we lose? An introduction to JOEI Forum on multidimensional poverty. J. Econ. Inequal. 2011, 9, 227-234. [CrossRef]

16. Kirby, M.; Mainuddin, M. Water and agricultural productivity in the Lower Mekong Basin: Trends and future prospects. Water Int. 2009, 34, 134-143. [CrossRef]

17. Sumner, D.; Christie, M.E.; Boulakia, S. Conservation agriculture and gendered livelihoods in Northwestern Cambodia: Decisionmaking, space and access. Agric. Hum. Values 2017, 34, 347-362. [CrossRef]

18. Njie, N.-I.; Ndiaye, T. Women and Agricultural Water Resource Management. UN Chronicle. 2021. Available online: https: //www.un.org/en/chronicle/article/women-and-agricultural-water-resource-management (accessed on 28 April 2018).

19. Gatke, P. Women's Participation in Community Fisheries Committees in Cambodia; Roskilde University: Roskilde, Denmark, 2008.

20. Siciliano, G.; Urban, F.; Kim, S.; Lonn, P.D. Hydropower, social priorities and the rural-urban development divide: The case of large dams in Cambodia. Energy Policy 2015, 86, 273-285. [CrossRef]

21. Pheakdey, H. Hydropower and local community: A case study of the Kamchay dam, a China-funded hydropower project in Cambodia. Community Dev. 2017, 48, 385-402. [CrossRef]

22. Sumner, A. From Deprivation to Distribution: Is Global Poverty Becoming A Matter of National Inequality? IDS Work. Pap. 2012, 2012, 1-36. [CrossRef]

23. Collentine, D. Water Resource Economics: The Analysis of Scarcity, Policies and Projects. Eur. Rev. Agric. Econ. 2006, 33, 437-439. [CrossRef]

24. Forni, L.G.; Escobar, M.I.; Moncada, A. Examining Poverty and Equality in Water Resources Planning: A Colombia Case Study. 2018. Available online: https://www.sei.org/wp-content/uploads/2018/08/examining-poverty-and-equality-in-waterresources-planning.pdf (accessed on 15 April 2018).

25. Terrazas, L.; Forni, L.; Escobar, M. Integrating equality in evaluation of water access for irrigation in an Andean community. AQUALAC 2020, 12, 42-58. [CrossRef]

26. Lempert, R.J. Shaping the Next one Hundred Years: New Methods for Quantitative, Long-Term Policy Analysis; RAND: Santa Monica, CA, USA, 2003.

27. Purkey, D.; Arias, M.I.E.; Mehta, V.K.; Forni, L.; Depsky, N.J.; Yates, D.N.; Stevenson, W.N. A Philosophical Justification for a Novel Analysis-Supported, Stakeholder-Driven Participatory Process for Water Resources Planning and Decision Making. Water 2018, 10, 1009. [CrossRef]

28. Forni, L.G.; Galaitsi, S.; Mehta, V.K.; Escobar, M.I.; Purkey, D.R.; Depsky, N.J.; Lima, N.A. Exploring scientific information for policy making under deep uncertainty. Environ. Model. Softw. 2016, 86, 232-247. [CrossRef]

29. Bresney, S.R.; Forni, L.; Mautner, M.R.L.; Huber-Lee, A.; Shrestha, M.; Moncada, A.M.; Ghosh, E.; Sopharith, T. Investigating Tradeoffs between Agricultural Development and Environmental Flows under Climate Change in the Stung Chinit Watershed, Cambodia. Hydrology 2020, 7, 95. [CrossRef]

30. Fowler, H.J.; Kilsby, C.G.; O'Connell, P.E. Modeling the impacts of climatic change and variability on the reliability, resilience, and vulnerability of a water resource system. Water Resour. Res. 2003, 39. [CrossRef]

31. Sandoval-Solis, S.; McKinney, D.; Loucks, D. Sustainability Index for Water Resources Planning and Management. J. Water Resour. Plan. Manag. 2011, 137, 381-390. [CrossRef]

32. McInerney, D.; Lempert, R.; Keller, K. What are robust strategies in the face of uncertain climate threshold responses? Clim. Chang. 2012, 112, 547-568. [CrossRef]

33. Herman, J.D.; Reed, P.M.; Zeff, H.B.; Characklis, G.W. How Should Robustness Be Defined for Water Systems Planning under Change? J. Water Resour. Plan. Manag. 2015, 141, 04015012. [CrossRef]

34. Fletcher, S.M.; Miotti, M.; Swaminathan, J.; Klemun, M.M.; Strzepek, K.; Siddiqi, A. Water Supply Infrastructure Planning: Decision-Making Framework to Classify Multiple Uncertainties and Evaluate Flexible Design. J. Water Resour. Plan. Manag. 2017, 143, 04017061. [CrossRef]

35. Madani, K.; Shafiee-Jood, M. Socio-Hydrology: A New Understanding to Unite or a New Science to Divide? Water 2020, $12,1941$. [CrossRef]

36. di Baldassarre, G.; Viglione, A.; Carr, G.; Kuil, L.; Yan, K.; Brandimarte, L.; Bloschl, G. Debates-Perspectives on socio-hydrology: Capturing feedbacks between physical and social processes: A socio-hydrological approach to explore flood risk changes. Water Resour. Res. 2015, 51, 4770-4781. [CrossRef]

37. Troy, T.J.; Pavao-Zuckerman, M.; Evans, T.P. Debates-Perspectives on socio-hydrology: Socio-hydrologic modeling: Tradeoffs, hypothesis testing, and validation: Socio-hydrologic modeling. Water Resour. Res. 2015, 51, 4806-4814. [CrossRef] 
38. Konar, M.; Garcia, M.; Sanderson, M.R.; Yu, D.J.; Sivapalan, M. Expanding the Scope and Foundation of Sociohydrology as the Science of Coupled Human-Water Systems. Water Resour. Res. 2019, 55, 874-887. [CrossRef]

39. Sivapalan, M.; Savenije, H.H.G.; Blöschl, G. Socio-hydrology: A new science of people and water: Invited Commentary. Hydrol. Process. 2012, 26, 1270-1276. [CrossRef]

40. Wesselink, A.; Kooy, M.; Warner, J. Socio-hydrology and hydrosocial analysis: Toward dialogues across disciplines: Sociohydrology and hydrosocial analysis. Wiley Interdiscip. Rev. Water 2017, 4, e1196. [CrossRef]

41. Savelli, E.; Rusca, M.; Cloke, H.; di Baldassarre, G. Don't blame the rain: Social power and the 2015-2017 drought in Cape Town. J. Hydrol. 2021, 594, 125953. [CrossRef]

42. Brown, C.M.; Lund, J.R.; Cai, X.; Reed, P.; Zagona, E.A.; Ostfeld, A.; Hall, J.W.; Characklis, G.W.; Yu, W.; Brekke, L.D. The future of water resources systems analysis: Toward a scientific framework for sustainable water management: The future of water resources systems analysis. Water Resour. Res. 2015, 51, 6110-6124. [CrossRef]

43. Barnett, T.P.; Adam, J.C.; Lettenmaier, D.P. Potential impacts of a warming climate on water availability in snow-dominated regions. Nature 2005, 438, 303-309. [CrossRef]

44. Gleick, P.H. The World's Water. The Biennial Report on Freshwater Resources Volume 8. 2014. Available online: http:/ /search. ebscohost.com/login.aspx?direct=true\&scope=site\&db=nlebk\&db=nlabk\&AN=683268 (accessed on 30 December 2014).

45. Hayhoe, K.; Cayan, D.; Field, C.B.; Frumhoff, P.C.; Maurer, E.P.; Miller, N.L.; Moser, S.C.; Schneider, S.H.; Cahill, K.N.; Cleland, E.E.; et al. Emissions pathways, climate change, and impacts on California. Proc. Natl. Acad. Sci. USA 2004, 101, 12422-12427. [CrossRef]

46. UNESCO WWAP. The 2019 Water \& Gender Toolkit Has Been Launched. 2019. Available online: http://www.unesco.org/new/ en/natural-sciences/environment/water/wwap/display-single-news/news/the_2019_water_gender_toolkit_has_been_ launched/ (accessed on 15 April 2018).

47. Von Braun, J.; Gatzweiler, F.W. (Eds.) Marginality; Springer: Dordrecht, The Netherlands, 2014. [CrossRef]

48. Oxford Poverty and Human Development Initiative. Global Multidimensional Poverty Index 2018: The Most Detailed Picture to Date of the World's Poorest People; University of Oxford: Oxford, UK, 2018.

49. SIDA. Dimensions of Poverty Sida's Conceptual Framework. Sitrus. 2017. Available online: http:/ /www.sida.se/contentassets / 07acf1eb6c9e417db80a74b26692d40f/ebd4b37c-c50d-4081-810b-d7a1d5d63a44.pdf (accessed on 18 October 2019).

50. Yates, D.; Sieber, J.; Purkey, D.; Huber-Lee, A. WEAP21—A Demand-, Priority-, and Preference-Driven Water Planning Model. Water Int. 2005, 30, 487-500. [CrossRef]

51. Bun, S.; Oeurng, C.; Lim, V.; Hornbuckle, J. Estimating Rice Water Use using Water Balance Approach: Case study in Cambodia. Res. J. Sci. Technol. 2014, 2, 17-24.

52. Keskinen, M.; Kakonen, M.; Tola, P.; Varis, O. The Tonle Sap Lake, Cambodia: Water-related conflicts with abundance of water. Econ. Peace Secur. J. 2007, 2, 49-59. [CrossRef]

53. Nesbitt, H.J. (Ed.) Rice Production in Cambodia: Cambodia-Irri-Australia Project; International Rice Research Institute: Manila, Philippines, 1998.

54. CARDI Annual Report 2011. Available online: http://www.cardi.org/wp-content/uploads/downloads/2015/05/CARDIAnnual-Report-2011.pdf (accessed on 26 May 2020).

55. World Bank. Cambodia Halving Poverty by 2015? Poverty Assessment 2006. 35213-KH. 2006. Available online: http:/ / documents worldbank.org/curated/en/690271468222905334/pdf/352130REV0pdf.pdf (accessed on 26 July 2019).

56. Johnston, R.; Try, T.; de Silva, S. Agricultural Water Management Planning in Cambodia. International Water Management Institute (IWMI). 2013. Available online: http://www.iwmi.cgiar.org/Publications/issue_briefs/cambodia/issue_brief_01-awm_ planning_in_cambodia.pdf (accessed on 26 July 2019).

57. Smith, D.; Hornbuckle, J. A Review on Rice Productivity in Cambodia and Water Use Measurement Using Direct and Indirect Methods on a Dry Season Rice Crop; Technical Report to ACIAR; CSIRO Sustainable Agriculture Flagship: Canberra, Australia, 2013 ; p. 46.

58. Technical Coordination Unit for the Tonle Sap. Tole Sap Ecosystem and Value; Kingdom of Cambodia Ministry of Environment: Phnom Penh, Cambodia, 2001.

59. Teh, L.S.L.; Bond, N.; Kc, K.; Fraser, E.; Seng, R.; Sumaila, U.R. The economic impact of global change on fishing and non-fishing households in the Tonle Sap ecosystem, Pursat, Cambodia. Fish. Res. 2019, 210, 71-80. [CrossRef]

60. de Silva, S.; Johnston, R.; Senaratna Sellamuttu, S. Agriculture, Irrigation and Poverty Reduction in Cambodia: Policy Narratives and Ground Realities Compared; CGIAR Research Program on Aquatic Agricultural Systems; WorldFish: Penang, Malaysia, 2014; Working Paper: AAS-2014-13.

61. Sithirith, M. Water governance in Cambodia: From centralized water governance to farmer water user community. Resources 2017, 6, 44. [CrossRef]

62. Sithirith, M. Downstream State and Water Security in the Mekong Region: A Case of Cambodia between Too Much and Too Little Water. Water 2021, 13, 802. [CrossRef]

63. Pearse-Smith, S.W.D. 'Water War' in the Mekong Basin? Asia Pac. Viewp. 2012, 53, 147-162. [CrossRef]

64. USAID. Wealth Index. 2020. Available online: https://dhsprogram.com/topics/wealth-index/ (accessed on 2 March 2018).

65. Sieber, J.; Purkey, D. WEAP: Water Evaluation and Planning System User Guide; Stockholm Environment Institute (SEI).: Stockholm, Sweden, 2015; Available online: https:/ / www.weap21.org/downloads/WEAP_User_Guide.pdf (accessed on 26 May 2020). 
66. Allen, R.G.; Pereira, L.S.; Raes, D.; Smith, M. Crop Evapotranspiration Guidelines for Computing Crop Water Requirements; FAO Irrigation and Drainage Paper 56; Food and Agriculture Organization: Rome, Italy, 1998.

67. Sokhem, P.; Sunada, K. The Governance of the Tonle Sap Lake, Cambodia: Integration of Local, National and International Levels. Int. J. Water Resour. Dev. 2006, 22, 399-416. [CrossRef]

68. Sam, S.; Shinogi, Y. Performance assessment of Farmer Water User Community: A case study in Stung Chinit irrigation system, Cambodia. Paddy Water Environ. 2015, 13, 19-27. [CrossRef]

69. Park, C.M.Y.; Maffii, M. 'We are not afraid to die': Gender dynamics of agrarian change in Ratanakiri province, Cambodia. J. Peasant Stud. 2017, 44, 1235-1254. [CrossRef]

70. Olson, K.R.; Morton, L.W. Water rights and fights: Lao dams on the Mekong River. J. Soil Water Conserv. 2018, 73, 35A-41A [CrossRef]

71. Gätke, P.; Borin, U. The Kamchay Hydropower Dam: An Assessment of the Dam's Impacts on Local Communities and the Environment. 2013. Available online: http:/ / ngoforum.org.kh/files/hcpr_kam_chay_dam_eng.pdf (accessed on 10 June 2019).

72. Sam, S.; Pech, S. (Eds.) Climate Change and Water Governance in Cambodia: Challenge and Perspectives for Water Security and Climate Change in Selected Catchments, Cambodia; Cambodia Development Resource Institute: Phnom Penh, Cambodia, 2015.

73. Kuenzer, C.; Campbell, I.; Roch, M.; Leinenkugel, P.; Tuan, V.Q.; Dech, S. Understanding the impact of hydropower developments in the context of upstream-downstream relations in the Mekong river basin. Sustain. Sci. 2013, 8, 565-584. [CrossRef]

74. Stung Chinit Watershed Rapid Assessment Report. September 2020. Available online: https://www.swpwater.org/wp-content/ uploads/2020/10/SWP-Report-Water-Balance-in-the-Chinit-Watershed_September-24-2020.pdf (accessed on 26 May 2020).

75. Onishi, K. Reassessing Water Security in the Mekong: The Chinese Rapprochement with Southeast Asia. J. Nat. Resour. Policy Res. 2011, 3, 393-412. [CrossRef]

76. Brickell, K. 'We don't forget the old rice pot when we get the new one': Discourses on Ideals and Practices of Women in Contemporary Cambodia. Signs J. Women Cult. Soc. 2011, 36, 437-462. [CrossRef]

77. Hillenbrand, E.; Lakzadeh, P.; Sokhoin, L.; Talukder, Z.; Green, T.; McLean, J. Using the Social Relations Approach to capture complexity in women's empowerment: Using gender analysis in the Fish on Farms project in Cambodia. Gend. Dev. 2014, 22, 351-368. [CrossRef]

78. World Bank. Cambodia: Gender in Agriculture Assessment; Technical Assistance Note Report No: ACS13120; Agriculture Global Practice East Asia and Pacific Region; World Bank: Washington, DC, USA, 2015.

79. Promoting Women's Economic Empowerment in Cambodia; Asian Development Bank: Mandaluyong City, Philippines, 2015.

80. Johnson-Welch, C. USAID/Cambodia: Gender Assessment. 2010. Available online: https://pdf.usaid.gov/pdf_docs/Pdacr982 .pdf (accessed on 25 August 2020).

81. Resurreccion, B. Rules, Roles and Rights: Gender, Participation and Community Fisheries Management in Cambodia's Tonle Sap Region. Int. J. Water Resour. Dev. 2006, 22, 433-447. [CrossRef]

82. Ministry of Women's Affaires. Neary Rattanak V: Five Year Strategic Plan for Strengthening Gender Mainstreaming and Women's Empowerment 2019-2023. 2020. Available online: https://www.mowa.gov.kh/wp-content/uploads/2021/02/Neary-RattanakV-final-Eng.pdf (accessed on 10 December 2020).

83. RGC (Royal Government of Cambodia. National Strategic Development Plan 2019-2023. 2019. Available online: https: / / data.opendevelopmentmekong.net/dataset/087e8a03-f09d-4eb2-94f2-00d8d237b342/resource/bb62a621-8616-4728-842f-33ce7 e199ef3/download/nsdp-2019-2023_en.pdf (accessed on 20 April 2020).

84. National Climate Change Committee. Cambodia Climate Change Strategic Plan. 2013. Available online: https://www. cambodiaip.gov.kh/DocResources /ab9455cf-9eea-4adc-ae93-95d149c6d78c_007729c5-60a9-47f0-83ac-7f70420b9a34-en.pdf (accessed on 26 May 2020).

85. Ministry of Women's Affaires. Master Plan on Gender and Climate Change 2018-2030. 2018; Gender and Climate Change Committee. Available online: https:/ /ncsd.moe.gov.kh/sites/default/files/2019-06/MASTER\%20PLAN\%20ON\%20GENDER\% 20AND\%20CLIMATE\%20CHANGE.pdf (accessed on 8 July 2019). 